\title{
EnergyPlus vs. Monthly ISO 13790 for Israeli Climatic Zones
}

\author{
By Samuel Hassid ${ }^{*}$
}

The energy efficiency, as predicted using on one hand the comprehensive building energy calculation program EnergyPlus and on the other hand the simplified monthly method of Standard ISO (EN) 13790, is compared for the four climatic zones of Israel. In two of those zones (Coastal and Negev Zones) cooling is dominant but heating is important; in another one, the Mountain Region, heating is dominant but cooling important and in the fourth one (Syrian-African Rift) there is essentially only cooling. The energy efficiency predicted by the two models is quantified as the percent reduction of annual heating plus cooling energy per unit area with respect to a pre-defined reference building. It is shown to be in fair agreement - with the simplified model being consistent with slightly better energy efficiency. The comparison is thought to be of relevance not only for the climates of Israel, but also for other climates in which cooling energy is as important as heating energy or more. The limitations of the comparison are discussed - especially the 24 hour heating/cooling assumption and the neglect of cooling latent heat in some regions.

Keywords: Building Simulation, Cooling, Energy Efficiency, Energy Standards, Heating.

\section{Introduction}

The effort to reduce energy consumption in most countries resulted in standards or regulations aiming at classifying buildings on the basis of their energy efficiency. These required ways of estimating the average energy consumption and performance of buildings. The differences between the predictions of the various software packages for estimating energy consumption of buildings are analyzed in numerous references (Crawley et al., 2005; Kokogiannakis et al., 2008; Kalema et al., 2008; Raslan and Davies, 2010, 2012; Summerfield et al., 2011; Schwarz and Raslan, 2013; Zhou et al., 2013).

In Israel the grading of the energy performance of buildings is required by the relatively new Energy Standards on Energy Performance of the Envelope of Buildings (Israel Standard 5280) ${ }^{1}$ as well as the Standards on Green Buildings (Israel Standard 5281) ${ }^{2}$ and Energy Rating of Buildings (Israel Standard 5282/1). ${ }^{3}$ IS 5281 on Green Buildings is concerned with many issues including soil, water, materials, health and welfare, waste disposal, transport, site management and innovation, but energy is by far the most important one (but not the unique). To evaluate the energy performance - a standard for classifying different kinds of

\footnotetext{
*Associate Professor, Technion - Israel Institute of Technology, Israel.

${ }^{1}$ Israel Standard 5280, 2012 - Part 1.1. Energy in Buildings: Building envelope - Residential Buildings (2012). [In Hebrew].

${ }^{2}$ Israel Standard 5281, 2005. Buildings with Reduced Environmental Impact. ("Green Buildings"). [In Hebrew].

${ }^{3}$ Israel Standard 5282/1, 2011 Energy Rating of Buildings: Residential Buildings. [In Hebrew].
} 
buildings was established, IS 5282, Standard for Energy Rating for Buildings, in which two options are considered, the Prescriptive one (not further considered in this work) and the Performance one.

Figure 1. Schematic View of Reference Apartment for Energy Performance

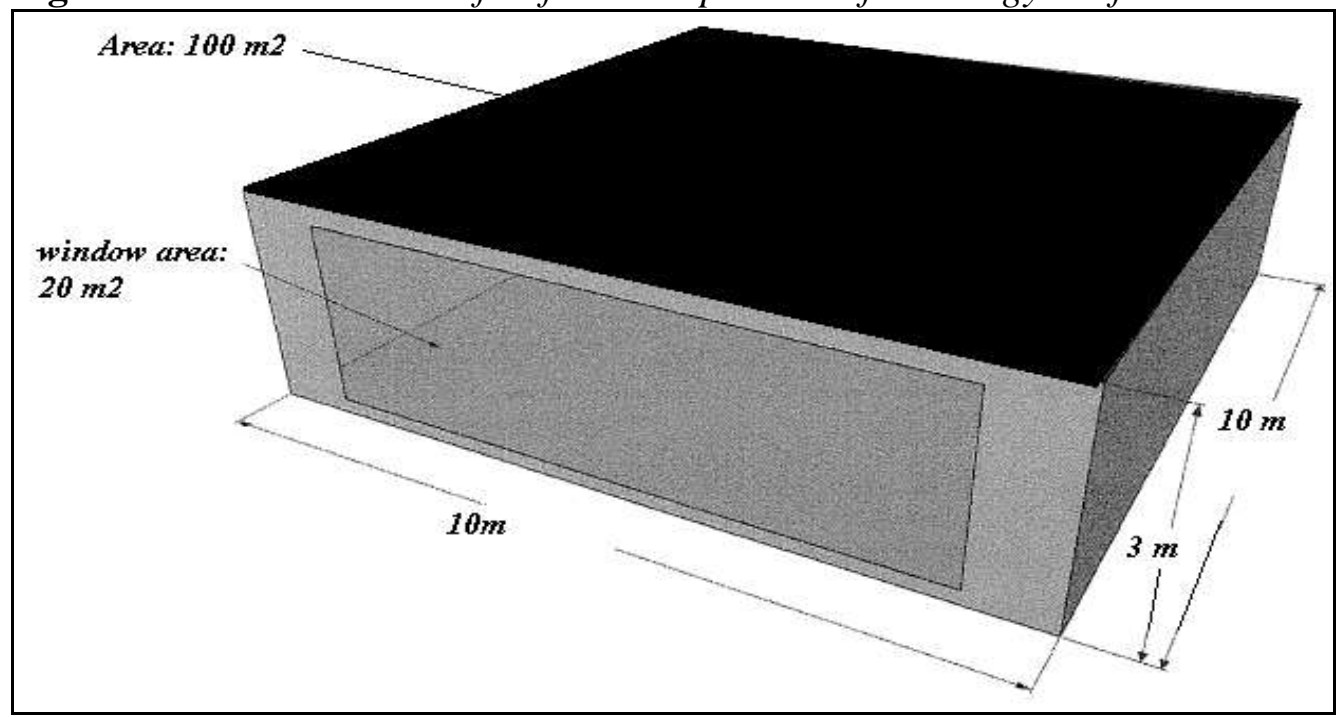

In the performance option - first the predicted, $E P_{\text {res }}$, the Annual Energy Consumption per square meter (sqm) of a (mediocre) reference building of 100 sqm is calculated (Figure 1). The properties of the envelope (consistent with the minimum requirements of Israeli Insulation Standard for Buildings 1045) ${ }^{4}$ as well as predetermined schedules for lighting, equipment and shading of openings are specified for each climate zone in Israel Standard 5282. Subsequently the Annual Energy Consumption per sqm $(E P)$ of the actual building under design is calculated, for the specified operation schedules. The percent reduction of the annual energy consumption of the building under design relatively to the reference building is used as a basis for classification (Table 1 - for the four climate regions of Israel, to be discussed later).

In addition to the Standard for Energy Grading of Buildings, a Standard for Energy Performance of the Building Envelope (IS 5280) has been established for several categories of buildings. It provides for three methodologies - prescriptive, semi-prescriptive and performance. For the performance methodology - a procedure similar to the one of the previously outlined IS 5282 is used - but in this standard there is a requirement for the maximum energy consumption per unit area:

1. For building unit area equal or above $70 \mathrm{sqm}$, the Annual Energy per Unit Area $(E P)$ should not exceed $0.9 \times E P_{\text {res }}\left(E P<0.9 E P_{\text {res }}\right)$.

2. For building unit area below $70 \mathrm{sqm}$, the Annual Energy per Unit Area should not exceed $1.06 \times E P_{\text {res }}\left(E P<1.06 E P_{\text {res }}\right)$.

${ }^{4}$ Israel Standard 1045 Insulation of Buildings. [In Hebrew]. 
Table 1. Classification vs. \% Energy Reduction in Residential Buildings according to Israel Standard IS 5280

\begin{tabular}{|c|c|c|c|c|}
\hline Category & Region A & Region B & Region C & Region D \\
\hline A+ & $>35$ & $>35$ & $>40$ & $>29$ \\
\hline A & $>30$ & $>30$ & $>34$ & $>26$ \\
\hline B & $>25$ & $>25$ & $>27$ & $>23$ \\
\hline C & $>20$ & $>20$ & $>20$ & $>20$ \\
\hline D & $>10$ & $>10$ & $>10$ & $>10$ \\
\hline E & $\mathbf{1 0}>$ & $\mathbf{1 0}>$ & $\mathbf{1 0}>$ & $\mathbf{1 0}>$ \\
\hline F & $\mathbf{0 >}$ & $\mathbf{0}>$ & $\mathbf{0}>$ & $\mathbf{0}>$ \\
\hline
\end{tabular}

To calculate $E P_{\text {res }}$ and $E P$, as required by both IS 5280 and 5282, a model for energy calculation is needed. The standards mention that the calculation model should satisfy the requirements of EN $15265^{5}$ for general criteria and validation of calculation methods of energy needs for space heating and cooling using dynamic methods. In IS 5280 ENERGYui is mentioned, a program based on EnergyPlus with a suitable front end developed in the Architecture Faculty of the Technion Israel Institute of Technology, designed to test compliance with Israeli Energy Standards 5282 and 5280. This application has been received favorably by the community of architects in Israel.

\section{Climatic Regions of Israel}

Although Israel is a small country, it is characterized by several climatic zones very different from each other, reflecting its being located in the transition region from Mediterranean climate to Desert Sub-Tropical climate (Figure 2).

1. Mediterranean Coast (A - Aleph) with a Mediterranean climate

2. Internal Coastal Area and Negev climate (B - Bet)

3. Mountain climate (C - Gimel)

4. Sub-tropical climate along the African-Syrian rift valley (D - Dalet)

In Regions A and B the cooling period is dominant, in the Mountain Region (C) the heating period is dominant but the cooling energy is still appreciable and in Region D there is almost no heating. The exact boundaries of the above regions are not well defined. They were originally defined in the Israel Insulation Standard IS 1045 and modified subsequently. In the actual standard today there is a list of all towns and villages in Israel with the corresponding zone classification. The characteristics of those climate zones are summarized in Table 2A,B.

${ }^{5}$ EN 15265 Energy performance of buildings - Calculation of energy needs for space heating and cooling using dynamic methods - General criteria and validation procedures.

${ }^{6}$ ENERGYui. Energyui.com. [In Hebrew]. 
Figure 2. Climatic Zones in Israel (Approximately and for Insulation of Buildings Only)

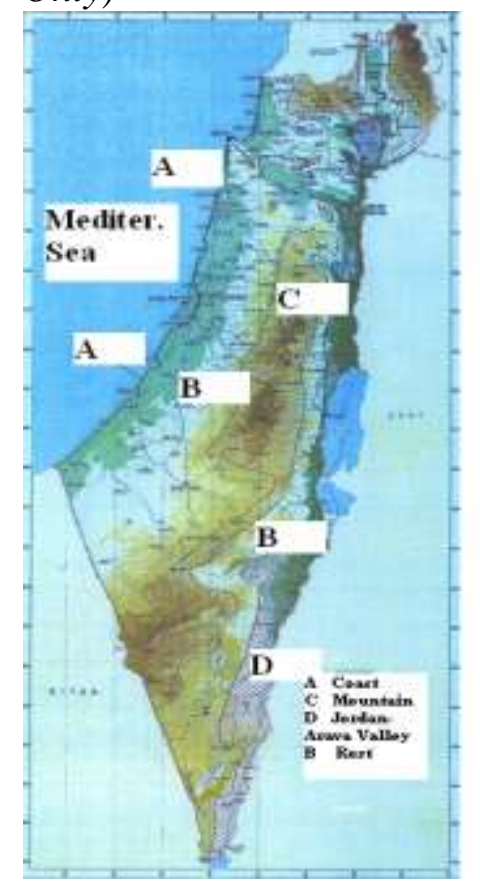

Table 2A. Main Characteristics of Climate Zones in Israel (Long. 35E, Lat. 32N)

\begin{tabular}{|c|c|c|c|c|c|}
\hline & & $\begin{array}{l}\text { Koeppen } \\
\text { climate class }\end{array}$ & $\begin{array}{c}\text { Heating } \\
\text { Degree } \\
\text { Days }\end{array}$ & $\begin{array}{l}\text { Monthly Av. } \\
\text { Temp Jan., }\end{array}$ & $\begin{array}{l}\text { Monthly Av. } \\
\text { Temp Aug., }\end{array}$ \\
\hline $\mathbf{A}$ & Tel-Aviv & Csa & 550 & 12.1 & 25.5 \\
\hline B & Beer-Sheva & Csb & 600 & 11.7 & 26.1 \\
\hline C & Jerusalem & Csb & 1050 & 8 & 23 \\
\hline D & Eilat & Bwh & 180 & 14.9 & 33 \\
\hline
\end{tabular}

Source: Bitan and Rubin, 1991.

Table 2B. Main Characteristics of Climate Zones in Israel (Long. 35E, Lat. 32N)

\begin{tabular}{|l|l|c|c|c|c|}
\hline \multicolumn{2}{|l|}{} & $\begin{array}{c}\text { Region } \\
\text { Koeppen } \\
\text { climate } \\
\text { class }^{8}\end{array}$ & $\begin{array}{c}\text { Relative } \\
\text { Humidity } \\
\text { Aug. 14:00, } \\
\%\end{array}$ & $\begin{array}{c}\text { Average } \\
\text { Daily Hor. } \\
\text { Global } \\
\text { Radiation, } \\
\text { Wh/m }\end{array}$ & $\begin{array}{c}\text { Average Daily } \\
\text { Hor. Diffuse } \\
\text { Radiation,Wh/m }\end{array}$ \\
\hline A & Tel-Aviv & Csa & $\mathbf{7 2}$ & $\mathbf{5 1 3 0}$ & $\mathbf{1 3 0 0}$ \\
\hline B & Beer-Sheva & Csb & $\mathbf{6 7}$ & $\mathbf{5 4 2 0}$ & $\mathbf{1 7 8 0}$ \\
\hline C & Jerusalem & Csb & $\mathbf{6 4}$ & $\mathbf{5 3 7 0}$ & $\mathbf{1 7 3 0}$ \\
\hline D & Eilat & Bwh & $\mathbf{2 9}$ & $\mathbf{5 5 6 0}$ & $\mathbf{1 3 6 0}$ \\
\hline
\end{tabular}

Source: Bitan and Rubin, 1991.

\footnotetext{
${ }^{7}$ http://www.weatheronline.co.uk/reports/climate/Israel-and-Palestine.htm.

${ }^{8} \mathrm{http}: / / \mathrm{www}$.weatheronline.co.uk/reports/climate/Israel-and-Palestine.htm.
} 


\section{ISO 13790 on Simplified Ways of Estimating Sensible Heating and Cooling}

Most European countries base their estimate of energy performance on European Norm/International Standard ISO/EN 13790. ${ }^{9}$ The standard contains two simplified approaches - one "monthly/yearly" (the term "static" is often used, perhaps not appropriately since the thermal mass/thermal time constant is taken into account, albeit empirically) and one "hourly". We will focus on the first, which is the most common simplified model used for classification of residential buildings. The climates of Israel give an opportunity to test ISO 13790 in climates dominated by cooling rather than heating needs, contrary to what is the case in Northern European climates, at least for residential buildings. Note that the comparison between software packages in the works mentioned in the introduction (see References list) do not consider ISO 13790.

\section{Simplified Monthly Model of ISO 13790}

The methodology of the monthly method of ISO 13790 consists of the following steps:

1. Calculate $L$ - the losses, in Wh, through the envelope by conduction and infiltration, based on the difference between the mean monthly temperature and the assumed set-point temperature.

$$
L=24 M\left(\sum U_{i} A_{i}+\frac{\rho c_{\text {pair }} N V}{3600}\right)\left(T_{\text {set }}-T_{o}\right)
$$

where $A_{i}$ is the area of each element, $U_{i}$ is the conductance of each element, $N$ is the infiltration rate in air changes per hour, $V$ the volume of the housing unit, $T_{\text {set }}$ the internal set point temperature, $T_{o}$ the outside average monthly temperature and $M$ the number of days in the month.

2. Calculate the monthly solar loads $S$ (through glazings) and internal heating loads $I$, in $\mathrm{Wh}$.

$$
S=M \sum G_{i} A_{i}
$$

where $G_{i}$ is the mean daily solar heat gain per unit area through window $i$.

3. Derive the gain to loss ratio $\gamma_{H}=(S+1) / L$ ratio for the months of the heating season and the loss to gain ratio $\gamma_{C}=L /(S+I)$ ratio for the months of the cooling one.

${ }^{9}$ ISO 13790 Energy Performance of Buildings - Calculation of Energy Use for Space Heating and Cooling. 
4. For the heating season, the utilization factor $\eta_{H}$ depends on $\gamma_{H}$. Once $\eta_{H}$ is calculated, the monthly heating needs $H$ can be calculated

$$
\begin{aligned}
& \eta_{H}=\frac{1-\gamma_{H}^{\alpha}}{1-\gamma_{H}^{\alpha+1}} \\
& H=L-\eta_{H}(S+I)
\end{aligned}
$$

5. For the cooling season, the heat transfer processes are usually dominated by internal and solar energy gains. Thus the cooling utilization factor $\eta_{C}$ depends on $\gamma_{C}=L /(S+1)$.

$$
\begin{aligned}
& \eta_{C}=\frac{1-\gamma_{C}^{\alpha}}{1-\gamma_{C}^{\alpha+1}} \text { for } L>0 \\
& \eta_{C}=1 \text { for } L<0 \\
& C=(S+I)-\eta_{C} L
\end{aligned}
$$

$L$ is positive if the set-point temperature exceeds the average monthly temperature and negative in the opposite case. The exponent $\alpha$ in both the expressions for heating and cooling is a function of the total thermal time constant $\tau$, i.e. the total thermal capacity of the building divided by the total loss coefficient.

$$
\tau=\frac{\sum C_{i} A_{i}}{\sum U_{i} A_{i}+\rho_{\text {air }} c_{\text {pair }} N V / 3600}
$$

where $C_{i}$ is the thermal capacity per unit area of surface element $i$ and the last term in the denominator is the loss coefficient due to infiltration/ventilation rate. The exponent $\alpha$ in Eqs. (3) and (5) is given by:

$$
\alpha=1+\frac{\tau}{\tau_{r e f}}
$$

where the reference time constant $\tau_{\text {ref }}$ is $15 \mathrm{~h}$. Exponent $\alpha$ may vary from 1 for no thermal mass to approximately 7 for very high thermal mass. (In ISO/EN 13790 one is allowed to introduce national rules for exponent $\alpha$ ).

\section{Subject of the Investigation}

The subject of this work is to calculate Heating, Cooling and Total Energy Needs for the Reference Home + an improved version of that Home (Improvement in insulation of walls and roofs, double glazing, infiltration reduced by $20 \%$ ) using: 
1. EnergyPlus (Version 7.0) ${ }^{10}$

2. ISO 13790 (monthly method)

This is done for several apartments:

1. Middle Floor

2. Upper Floor

3. Detached House above Raised Columns (Pilotis) (or Roof + Pilotis).

4. Detached House above Ground (or Roof + Ground Floor)

The calculations are repeated for the each of the four climate regions of Israel (A, B, C and D).

\section{Calculations}

The calculations are based on the reference building as defined in the Israeli Standards 5282 and 5280, in which the properties of the walls, the roof and the floor are defined, as well as the properties of the window and the amount of lighting and equipment internal load. The apartment is $10 \mathrm{~m} \times 10 \mathrm{~m}$ (100 sqm floor area) and $3 \mathrm{~m}$ high with a 20 sqm single-glazing on one face - and the basis of comparison of other buildings is the average annual energy for the four apartments with windows facing South, North, East and West. Subsequently the improved building is chosen, with $U$-values of walls equal to $80 \%$ of the corresponding ones in the reference building and infiltration equal to $80 \%$ of the one of the reference building and the single glazing of the reference building is replaced by double glazing. Contrary to the stipulations of IS 5282, it is not possible to incorporate night cooling for the cooling season. This cooling strategy is not properly taken into account in the monthly method of ISO 13790 in hot countries. Therefore 24 hour heating to $20^{\circ} \mathrm{C}$ during the heating period and 24 hour cooling to $24^{\circ} \mathrm{C}$ during the cooling period is assumed. For consistency, a uniform 50\% shading of the glazing is assumed, although in the actual standard there is some differentiation of the shading between seasons and climatic regions.

The climate data are based on the ones used in EnergyPlus (Bet-Dagan for Region A, Beer-Sheva for Region B, Jerusalem for Region C and Eilat for Region D) which can be downloaded from the EnergyPlus website. From these data the mean monthly temperature and the mean daily solar irradiation in different directions are calculated, to be used as simplified climate input for ISO 13790. The EnergyPlus version used is 7.0.0.

${ }^{10}$ EnergyPlus. http://apps1.eere.energy.gov/buildings/energyplus/. EnergyPlus Energy Simulation Software. 


\section{Results}

In Figures 3 to 4 the total annual heating and cooling energy per unit area, as calculated using EnergyPlus and ISO 13790, are shown for some of the chosen configurations and the four climatic zones for Israel. Agreement between the predictions of the two calculation methods can be judged to be fairly good, even though in some cases especially in Regions A (and B) this is a result of the difference in the cooling energy cancelled by the corresponding one in the heating energy. Cooling energy is shown to be dominant in Regions A and B whereas heating energy is dominant in Region $\mathrm{C}$ and in Region $\mathrm{D}$ there is almost no heating.

Figure 3A. Annual Heating + Cooling Energy per sqm for Middle Floor Apartment-Bet-Dagan (Region A)

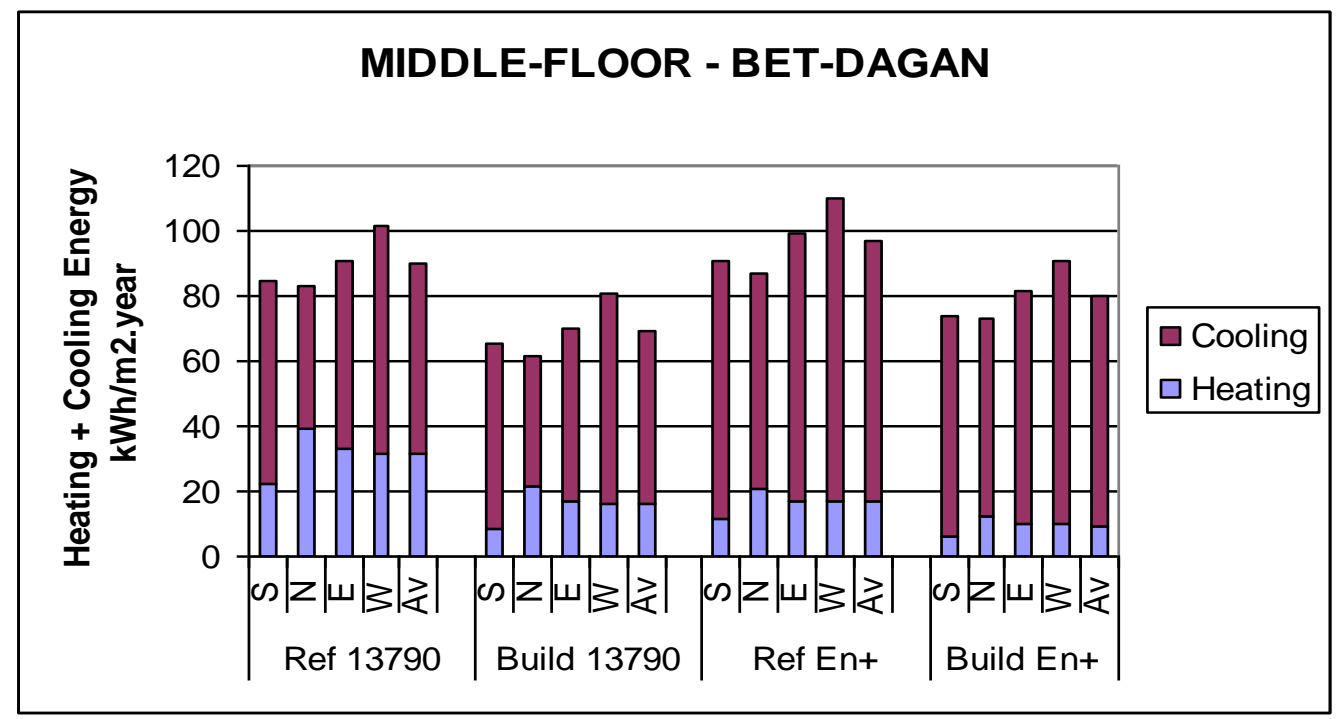

Figure 3B. Annual Heating + Cooling Energy per sqm for Middle Floor Apartment-Jerusalem (Region C)

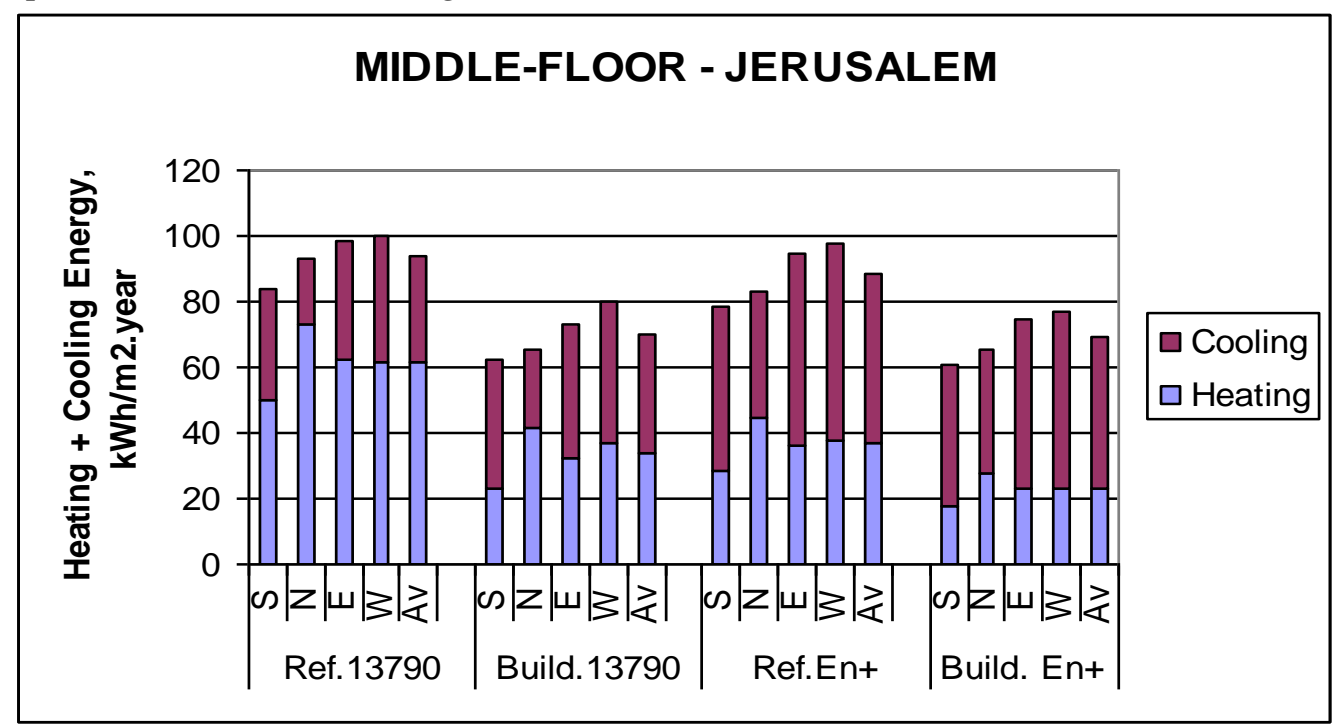


Figure 3C. Annual Heating + Cooling Energy per sq.m. for Middle Floor Apartment-Eilat (Region D)

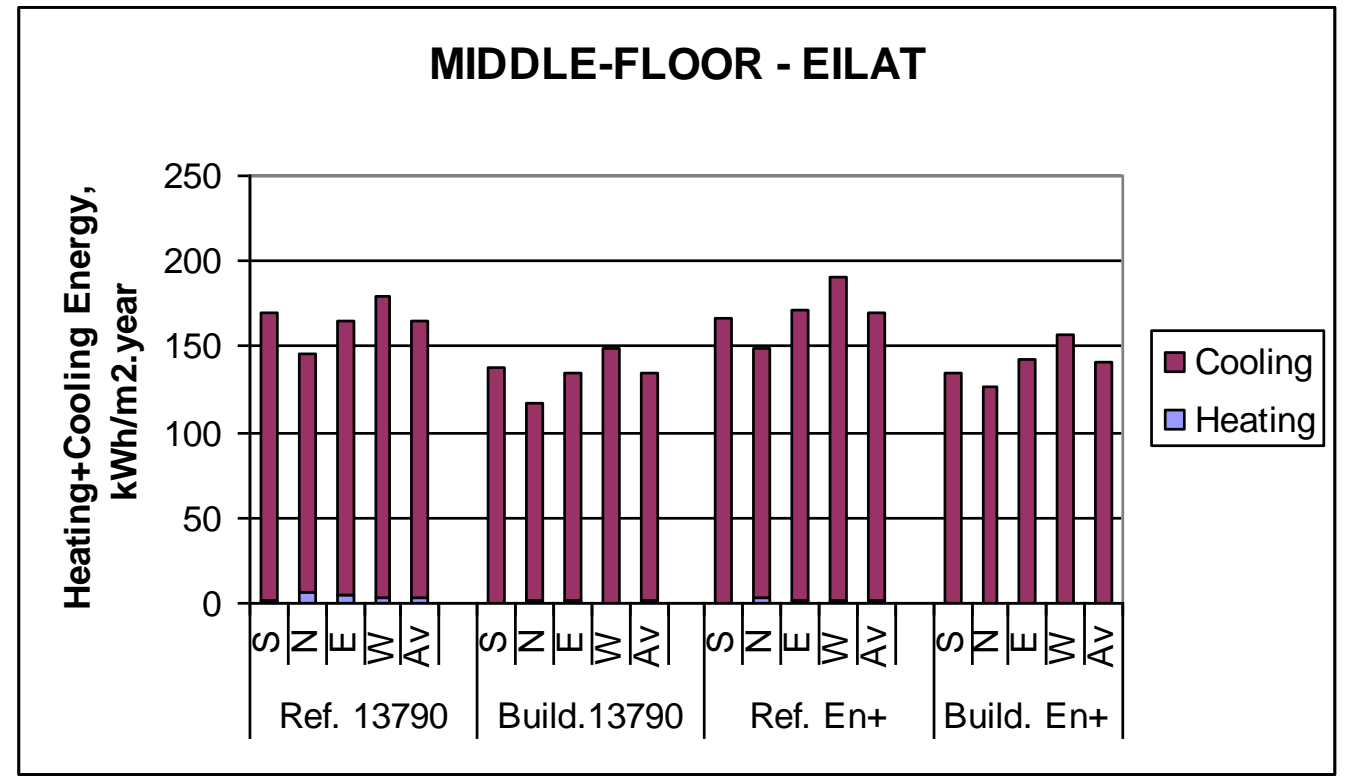

Figure 4A. Annual Heating + Cooling Energy per sqm for Upper Floor Apartment - Bet-Dagan (Region A)

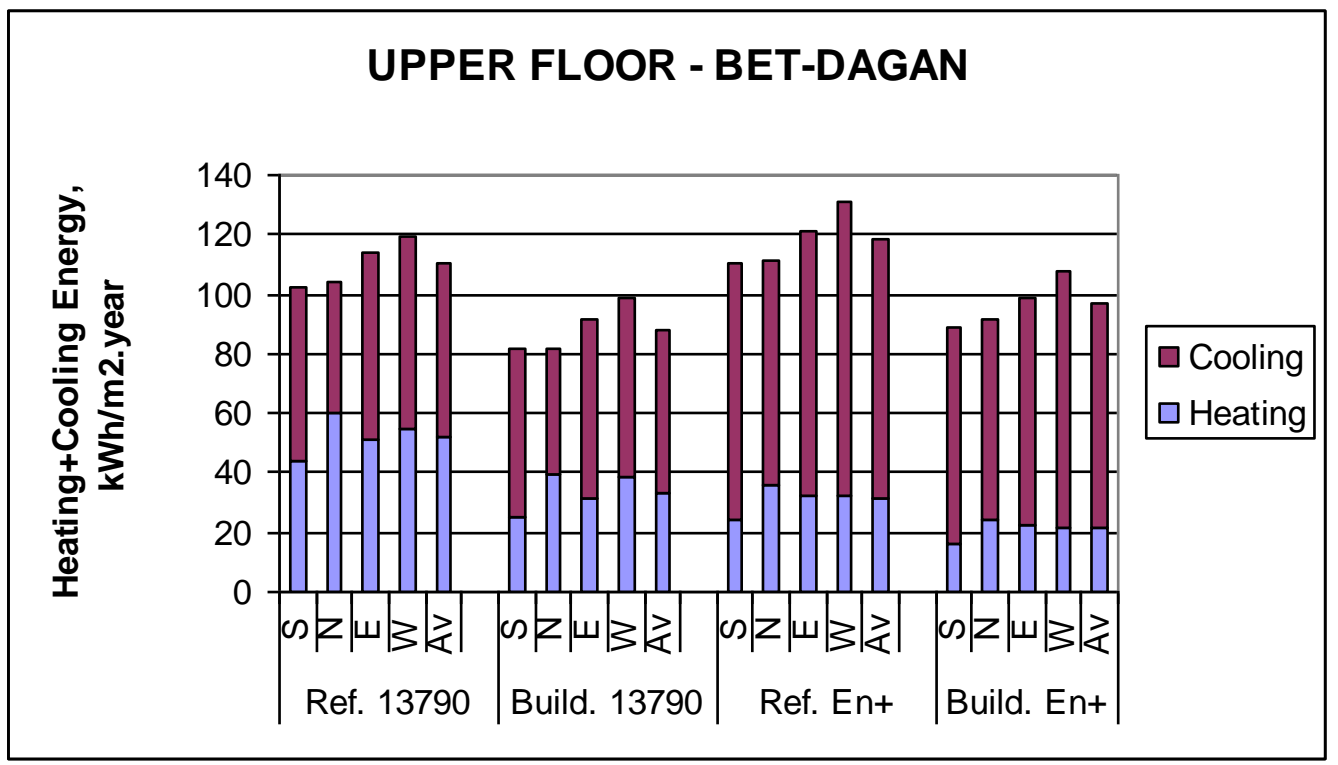


Figure 4B. Annual Heating + Cooling Energy per sqm for Upper Floor Apartment - Jerusalem (Region C)

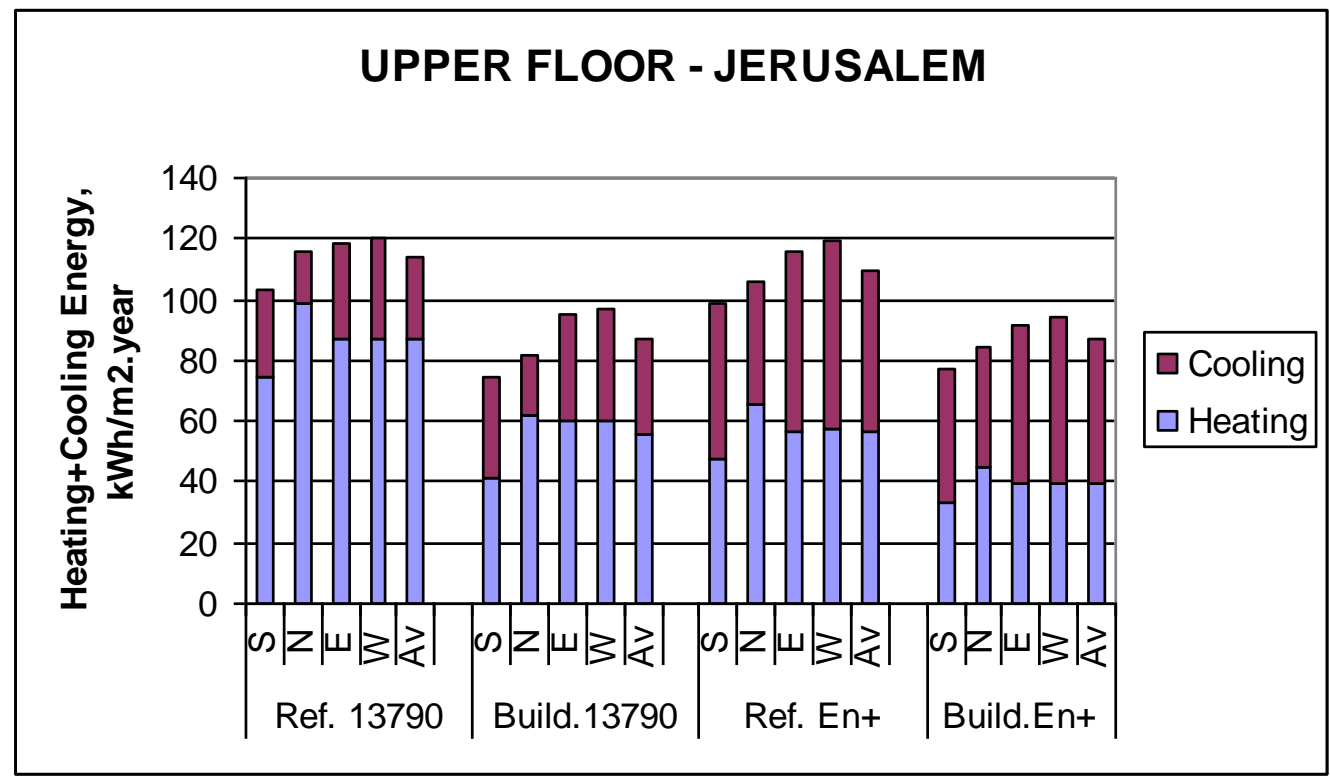

Figure 4C. Annual Heating + Cooling Energy per sqm for Upper Floor Apartment - Eilat (Region D)

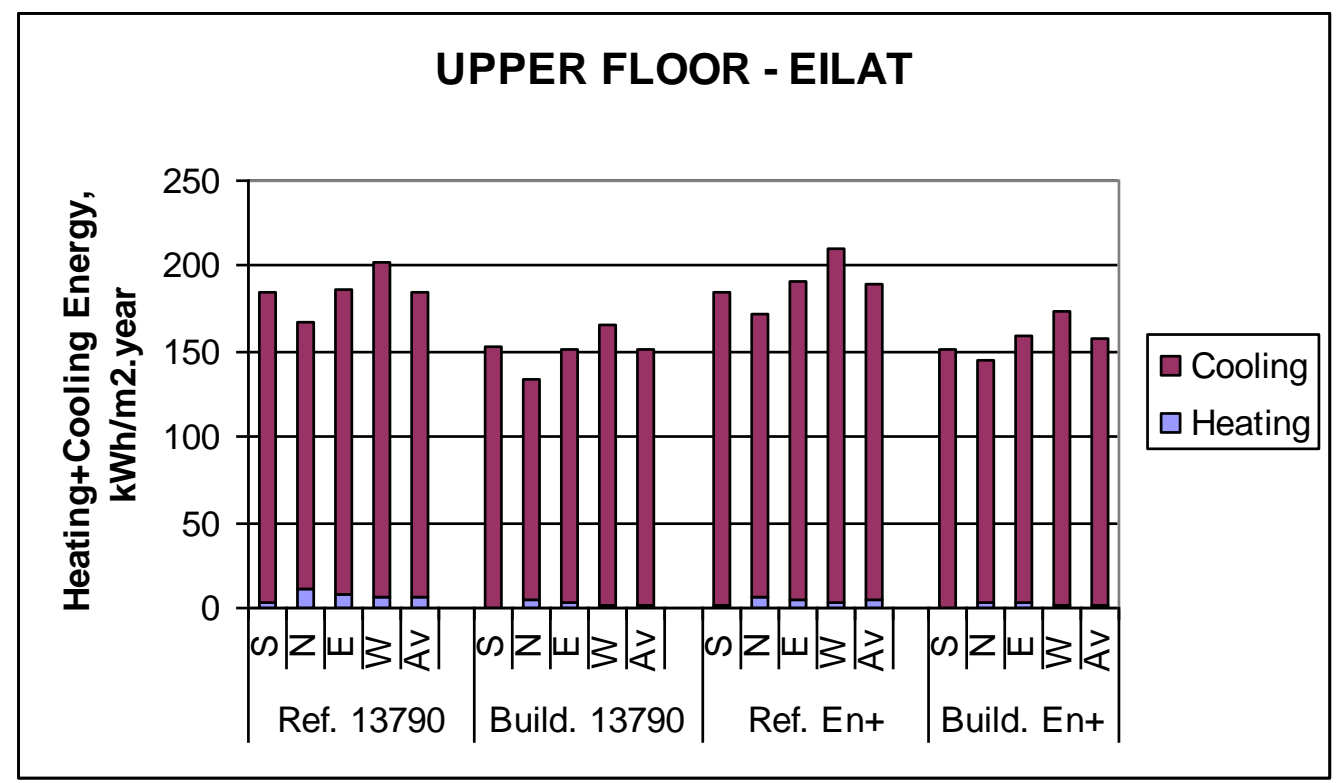

In Figures 5 to 8 the predicted reduction in annual energy needs of the improved building relative to the reference one is shown (Tables 3 to 6). 
Table 3A. Reduction of Cooling + Heating Energy + Category Bet-Dagan (Region A) Middle Floor

\begin{tabular}{|c|c|c|c|c|}
\hline $\begin{array}{c}\text { Window } \\
\text { orientation }\end{array}$ & $\begin{array}{c}\text { Reduction \% - } \\
\text { ISO 13790 }\end{array}$ & $\begin{array}{c}\text { Reduction \% - } \\
\text { EnergyPlus }\end{array}$ & $\begin{array}{c}\text { Energy category } \\
- \text { ISO13790 }\end{array}$ & $\begin{array}{c}\text { Energy } \\
\text { category - } \\
\text { EnergyPlus }\end{array}$ \\
\hline S & 27.4 & 24.0 & B & C+B \\
\hline N & 31.3 & 24.8 & A & C+B \\
\hline E & 22.0 & 15.6 & C & D \\
\hline W & 10.5 & 6.1 & D-E & E \\
\hline Average & 22.8 & 17.6 & C & D \\
\hline
\end{tabular}

Table 3B. Reduction of Cooling + Heating Energy + Category Beer-Sheva (Region B)-Middle Floor

\begin{tabular}{|c|c|c|c|c|}
\hline $\begin{array}{c}\text { Window } \\
\text { orientation }\end{array}$ & $\begin{array}{c}\text { Reduction \% - } \\
\text { ISO 13790 }\end{array}$ & $\begin{array}{c}\text { Reduction \% - } \\
\text { EnergyPlus }\end{array}$ & $\begin{array}{c}\text { Energy } \\
\text { category - } \\
\text { ISO13790 }\end{array}$ & $\begin{array}{c}\text { Energy } \\
\text { category - } \\
\text { EnergyPlus }\end{array}$ \\
\hline $\mathrm{S}$ & 24.8 & 24.8 & $\mathrm{C}+\mathrm{B}$ & $\mathrm{C}+\mathrm{B}$ \\
\hline $\mathrm{N}$ & 27.0 & 24.3 & $\mathrm{~B}$ & $\mathrm{C}+\mathrm{B}$ \\
\hline $\mathrm{E}$ & 17.4 & 15.9 & $\mathrm{D}$ & $\mathrm{D}$ \\
\hline $\mathrm{W}$ & 7.4 & 6.9 & $\mathrm{E}$ & $\mathrm{E}$ \\
\hline Average & 19.1 & 18.0 & $\mathrm{D}+\mathrm{C}$ & $\mathrm{D}$ \\
\hline
\end{tabular}

Table 3C. Reduction of Cooling + Heating Energy + Category Jerusalem (Region C) - Middle Floor

\begin{tabular}{|c|c|c|c|c|}
\hline $\begin{array}{c}\text { Window } \\
\text { orientation }\end{array}$ & $\begin{array}{c}\text { Reduction \% - } \\
\text { ISO 13790 }\end{array}$ & $\begin{array}{c}\text { Reduction \% - } \\
\text { EnergyPlus }\end{array}$ & $\begin{array}{c}\text { Energy category } \\
- \text { ISO13790 }\end{array}$ & $\begin{array}{c}\text { Energy } \\
\text { category - } \\
\text { EnergyPlus }\end{array}$ \\
\hline S & 33.9 & 31.7 & B+A & B \\
\hline N & 30.3 & 26.2 & B & C+B \\
\hline E & 22.1 & 15.9 & $\mathrm{C}$ & $\mathrm{D}$ \\
\hline W & 14.7 & 12.8 & $\mathrm{D}$ & $\mathrm{D}$ \\
\hline Average & 25.3 & 21.7 & $\mathrm{C}$ & $\mathrm{C}$ \\
\hline
\end{tabular}

Table 3D. Reduction of Cooling + Heating Energy + Category Eilat (Region D) Middle Floor

\begin{tabular}{|c|c|c|c|c|}
\hline $\begin{array}{c}\text { Window } \\
\text { orientation }\end{array}$ & $\begin{array}{c}\text { Reduction \% - } \\
\text { ISO 13790 }\end{array}$ & $\begin{array}{c}\text { Reduction \% - } \\
\text { EnergyPlus }\end{array}$ & $\begin{array}{c}\text { Energy category } \\
- \text { ISO13790 }\end{array}$ & $\begin{array}{c}\text { Energy } \\
\text { category - } \\
\text { EnergyPlus }\end{array}$ \\
\hline S & 16.0 & 20.2 & D & C-D \\
\hline $\mathrm{N}$ & 29.2 & 25.5 & A+-A & A-B \\
\hline E & 18.2 & 16.1 & D & D \\
\hline W & 9.3 & 7.1 & E+D & E \\
\hline Average & 18.2 & 17.2 & D & D \\
\hline
\end{tabular}


Table 4A. Reduction of Cooling + Heating Energy + Category Bet-Dagan (Region A) - Upper Floor

\begin{tabular}{|c|c|c|c|c|}
\hline $\begin{array}{c}\text { Window } \\
\text { orientation }\end{array}$ & $\begin{array}{c}\text { Reduction \% - } \\
\text { ISO 13790 }\end{array}$ & $\begin{array}{c}\text { Reduction \% - } \\
\text { EnergyPlus }\end{array}$ & $\begin{array}{c}\text { Energy } \\
\text { category - } \\
\text { ISO13790 }\end{array}$ & $\begin{array}{c}\text { Energy category } \\
- \text { EnergyPlus }\end{array}$ \\
\hline S & 25.7 & 25.1 & B-C & B-C \\
\hline N & 25.9 & 22.7 & B-C & C \\
\hline E & 17.1 & 16.6 & D & D \\
\hline W & 9.9 & 9.4 & E+D & E+D \\
\hline Average & 19.6 & 18.5 & D+C & D \\
\hline
\end{tabular}

Table 4B. Reduction of Cooling + Heating Energy + Category Beer-Sheva (Region B) - Upper Floor

\begin{tabular}{|c|c|c|c|c|}
\hline $\begin{array}{c}\text { Window } \\
\text { orientation }\end{array}$ & $\begin{array}{c}\text { Reduction \% - } \\
\text { ISO 13790 }\end{array}$ & $\begin{array}{c}\text { Reduction \% - } \\
\text { EnergyPlus }\end{array}$ & $\begin{array}{c}\text { Energy category } \\
- \text { ISO13790 }\end{array}$ & $\begin{array}{c}\text { Energy } \\
\text { category - } \\
\text { EnergyPlus }\end{array}$ \\
\hline S & 22.5 & 25.4 & C & B-C \\
\hline N & 24.4 & 22.3 & C+B & C \\
\hline E & 18.1 & 16.5 & D & D \\
\hline W & 10.9 & 9.5 & D-E & E+D \\
\hline Average & 19.0 & 18.4 & D & D \\
\hline
\end{tabular}

Table 4C. Reduction of Cooling + Heating Energy + Category Jerusalem (Region C) - Upper Floor

\begin{tabular}{|c|c|c|c|c|}
\hline $\begin{array}{c}\text { Window } \\
\text { orientation }\end{array}$ & $\begin{array}{c}\text { Reduction \% - } \\
\text { ISO 13790 }\end{array}$ & $\begin{array}{c}\text { Reduction \% - } \\
\text { EnergyPlus }\end{array}$ & $\begin{array}{c}\text { Energy category } \\
- \text { ISO13790 }\end{array}$ & $\begin{array}{c}\text { Energy } \\
\text { category - } \\
\text { EnergyPlus }\end{array}$ \\
\hline S & 34.6 & 29.9 & A-B & B \\
\hline N & 28.3 & 23.2 & B & C \\
\hline E & 16.9 & 16.6 & D & D \\
\hline W & 15.2 & 14.0 & D & D \\
\hline Average & 23.8 & 20.9 & C & C-D \\
\hline
\end{tabular}

Table 4D. Reduction of Cooling + Heating Energy + Category Eilat (Region B) Upper Floor

\begin{tabular}{|c|c|c|c|c|}
\hline $\begin{array}{c}\text { Window } \\
\text { orientation }\end{array}$ & $\begin{array}{c}\text { Reduction \% - } \\
\text { ISO 13790 }\end{array}$ & $\begin{array}{c}\text { Reduction \% - } \\
\text { EnergyPlus }\end{array}$ & $\begin{array}{c}\text { Energy category } \\
- \text { ISO13790 }\end{array}$ & $\begin{array}{c}\text { Energy } \\
\text { category - } \\
\text { EnergyPlus }\end{array}$ \\
\hline S & 17.4 & 20.7 & D & C-D \\
\hline N & 27.9 & 23.6 & A & B-C \\
\hline E & 18.5 & 16.0 & D & D \\
\hline W & 11.0 & 8.6 & D-E & E \\
\hline Average & 18.7 & 17.2 & D & D \\
\hline
\end{tabular}


Table 5A. Reduction of Cooling + Heating Energy + Category Bet-Dagan (Region A)-Roof + Pilotis Floor

\begin{tabular}{|c|c|c|c|c|}
\hline $\begin{array}{c}\text { Window } \\
\text { orientation }\end{array}$ & $\begin{array}{c}\text { Reduction \% - } \\
\text { ISO 13790 }\end{array}$ & $\begin{array}{c}\text { Reduction \% - } \\
\text { EnergyPlus }\end{array}$ & $\begin{array}{c}\text { Energy category } \\
- \text { ISO13790 }\end{array}$ & $\begin{array}{c}\text { Energy } \\
\text { category - } \\
\text { EnergyPlus }\end{array}$ \\
\hline $\mathrm{S}$ & 25.6 & 18.0 & B-C & D \\
\hline $\mathrm{N}$ & 23.8 & 14.7 & $\mathrm{C}$ & $\mathrm{D}$ \\
\hline $\mathrm{E}$ & 19.3 & 10.0 & $\mathrm{D}+\mathrm{C}$ & $\mathrm{E}+\mathrm{D}$ \\
\hline $\mathrm{W}$ & 12.8 & 3.9 & $\mathrm{D}$ & $\mathrm{E}$ \\
\hline Average & 20.4 & 11.6 & $\mathrm{C}-\mathrm{D}$ & $\mathrm{D}$ \\
\hline
\end{tabular}

Table 5B. Reduction of Cooling + Heating Energy + Category Beer-Sheva (Region B) - Roof + Pilotis Floor

\begin{tabular}{|c|c|c|c|c|}
\hline $\begin{array}{c}\text { Window } \\
\text { orientation }\end{array}$ & $\begin{array}{c}\text { Reduction \% - } \\
\text { ISO 13790 }\end{array}$ & $\begin{array}{c}\text { Reduction \% - } \\
\text { EnergyPlus }\end{array}$ & $\begin{array}{c}\text { Energy category } \\
- \text { ISO13790 }\end{array}$ & $\begin{array}{c}\text { Energy } \\
\text { category - } \\
\text { EnergyPlus }\end{array}$ \\
\hline S & 25.5 & 18.2 & B-C & C \\
\hline N & 22.9 & 14.6 & C & C-D \\
\hline E & 18.4 & 10.0 & D & D \\
\hline W & 12.7 & 4.1 & D & D-E \\
\hline Average & 19.8 & 11.7 & D+C & D \\
\hline
\end{tabular}

Table 5C. Reduction of Cooling + Heating Energy + Category Jerusalem (Region C) - Roof + Pilotis Floor

\begin{tabular}{|c|c|c|c|c|}
\hline $\begin{array}{c}\text { Window } \\
\text { orientation }\end{array}$ & $\begin{array}{c}\text { Reduction \% } \\
\text { ISO 13790 }\end{array}$ & $\begin{array}{c}\text { Reduction \% - } \\
\text { EnergyPlus }\end{array}$ & $\begin{array}{c}\text { Energy category } \\
- \text { ISO13790 }\end{array}$ & $\begin{array}{c}\text { Energy } \\
\text { category - } \\
\text { EnergyPlus }\end{array}$ \\
\hline S & 35.9 & 28.8 & A & B \\
\hline N & 28.5 & 21.6 & B & C \\
\hline E & 26.8 & 17.4 & C+B & D \\
\hline W & 25.7 & 15.2 & C & D \\
\hline Average & 29.2 & 20.8 & B & C-D \\
\hline
\end{tabular}

Table 5D. Reduction of Cooling + Heating Energy + Category Eilat (Region D) Roof + Pilotis Floor

\begin{tabular}{|c|c|c|c|c|}
\hline $\begin{array}{c}\text { Window } \\
\text { orientation }\end{array}$ & $\begin{array}{c}\text { Reduction \% } \\
\text { ISO 13790 }\end{array}$ & $\begin{array}{c}\text { Reduction \% - } \\
\text { EnergyPlus }\end{array}$ & $\begin{array}{c}\text { Energy category } \\
- \text { ISO13790 }\end{array}$ & $\begin{array}{c}\text { Energy } \\
\text { category - } \\
\text { EnergyPlus }\end{array}$ \\
\hline S & 19.0 & 20.8 & D & C-D \\
\hline N & 26.0 & 21.8 & B+A & C \\
\hline E & 18.5 & 15.8 & D & D \\
\hline W & 12.6 & 9.7 & D & E+D \\
\hline Average & 19.0 & 17.0 & D+C & D \\
\hline
\end{tabular}


Table 6A. Reduction of Cooling + Heating Energy + Category Bet-Dagan (Region A) - Roof + Ground Floor

\begin{tabular}{|c|c|c|c|c|}
\hline $\begin{array}{c}\text { Window } \\
\text { orientation }\end{array}$ & $\begin{array}{c}\text { Reduction \% - } \\
\text { ISO 13790 }\end{array}$ & $\begin{array}{c}\text { Reduction \% - } \\
\text { EnergyPlus }\end{array}$ & $\begin{array}{c}\text { Energy category } \\
- \text { ISO13790 }\end{array}$ & $\begin{array}{c}\text { Energy } \\
\text { category - } \\
\text { EnergyPlus }\end{array}$ \\
\hline S & 26.7 & 25.5 & B & B-C \\
\hline N & 26.8 & 22.9 & B & C \\
\hline E & 20.2 & 18.3 & C-D & D \\
\hline W & 12.4 & 11.6 & D & D \\
\hline Average & 21.5 & 19.6 & C & D+C \\
\hline
\end{tabular}

Table 6B. Reduction of Cooling + Heating Energy + Category Beer-Sheva $($ Region B) - Roof + Ground Floor

\begin{tabular}{|c|c|c|c|c|}
\hline $\begin{array}{c}\text { Window } \\
\text { orientation }\end{array}$ & $\begin{array}{c}\text { Reduction \% - } \\
\text { ISO 13790 }\end{array}$ & $\begin{array}{c}\text { Reduction \% - } \\
\text { EnergyPlus }\end{array}$ & $\begin{array}{c}\text { Energy category } \\
- \text { ISO13790 }\end{array}$ & $\begin{array}{c}\text { Energy } \\
\text { category - } \\
\text { EnergyPlus }\end{array}$ \\
\hline S & 27.2 & 26.2 & B & B \\
\hline N & 23.8 & 22.9 & C & C \\
\hline E & 19.3 & 18.3 & D+C & D \\
\hline W & 11.2 & 11.6 & D & D \\
\hline Average & 20.4 & 19.7 & C-D & D+C \\
\hline
\end{tabular}

Table 6C. Reduction of Cooling + Heating Energy + Category Jerusalem (Region C) - Roof + Ground Floor

\begin{tabular}{|c|c|c|c|c|}
\hline $\begin{array}{c}\text { Window } \\
\text { orientation }\end{array}$ & $\begin{array}{c}\text { Reduction \% - } \\
\text { ISO 13790 }\end{array}$ & $\begin{array}{c}\text { Reduction \% - } \\
\text { EnergyPlus }\end{array}$ & $\begin{array}{c}\text { Energy category } \\
- \text { ISO13790 }\end{array}$ & $\begin{array}{c}\text { Energy } \\
\text { category - } \\
\text { EnergyPlus }\end{array}$ \\
\hline S & 33.6 & 28.7 & B+A & B \\
\hline N & 24.8 & 21.0 & C & C \\
\hline E & 24.0 & 17.7 & C & D \\
\hline W & 23.0 & 15.5 & C & D \\
\hline Average & 26.3 & 20.7 & C+B & C-D \\
\hline
\end{tabular}

Table 6D. Reduction of Cooling + Heating Energy + Category Eilat (Region D) Roof + Ground Floor

\begin{tabular}{|c|c|c|c|c|}
\hline $\begin{array}{c}\text { Window } \\
\text { orientation }\end{array}$ & $\begin{array}{c}\text { Reduction \% - } \\
\text { ISO 13790 }\end{array}$ & $\begin{array}{c}\text { Reduction \% - } \\
\text { EnergyPlus }\end{array}$ & $\begin{array}{c}\text { Energy category } \\
- \text { ISO13790 }\end{array}$ & $\begin{array}{c}\text { Energy } \\
\text { category - } \\
\text { EnergyPlus }\end{array}$ \\
\hline S & 18.2 & 15.2 & D & D \\
\hline N & 26.2 & 16.2 & A-B & D \\
\hline E & 18.3 & 9.7 & D & E+D \\
\hline W & 12.1 & 3.2 & D & E \\
\hline Average & 18.7 & 11.1 & D & D \\
\hline
\end{tabular}

This is different from the actual calculations according to the Israeli Standard 5280 and 5282 where one takes into account the total annual electric energy consisting of heating, cooling plus lighting electric energy. In those standards the electric energy consumption of the air-conditioning devices for heating and 
cooling is obtained by dividing the heating and cooling energy needs by a coefficient of performance (COP) of 3. Given that in Israel most electric airconditioners are used for both heating and cooling, it is assumed in Standards 5282 and 5280 that both heating and cooling is done by electric air-conditioners with equal COP in summer and winter. In this work though, no assumptions are necessary for the value of COP and calculations of efficiency are based on heating plus cooling energy through the envelope of the building unit, with no consideration for the actual heating or cooling system. On the basis of energy needs reduction relatively to the reference unit and Table 1 the energy category is determined and shown in Figures 5 to 8 and Tables 3 to 6 . In the marginal cases (less than $1 \%$ from the border value of energy percentage reduction between two categories), both categories are shown. For example, if the reduction is $19.5 \%$ then Category D+C is indicated, whereas for $20.5 \%$ the Category is C-D.

Figure 5A. Reduction of Heating + Cooling Energy for Middle Floor ApartmentBet-Dagan (Region A). Categories shown above

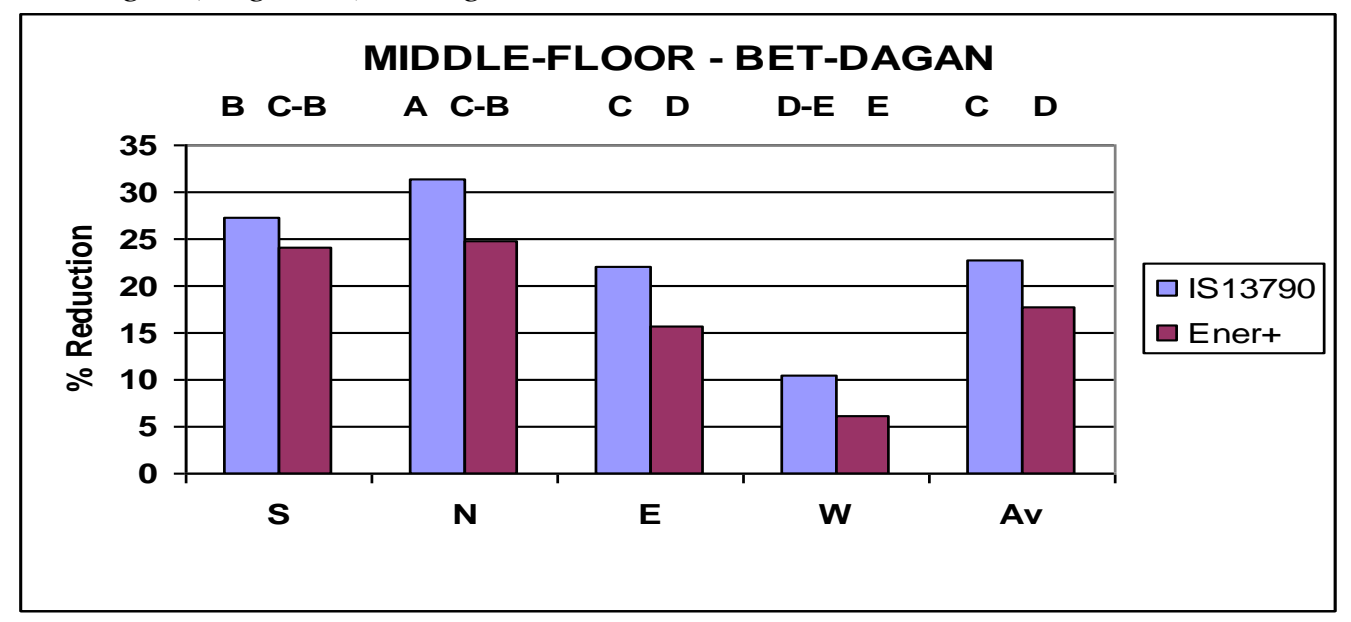

Figure 5B. Reduction of Heating + Cooling Energy for Middle Floor ApartmentBeer-Sheva (Region B)

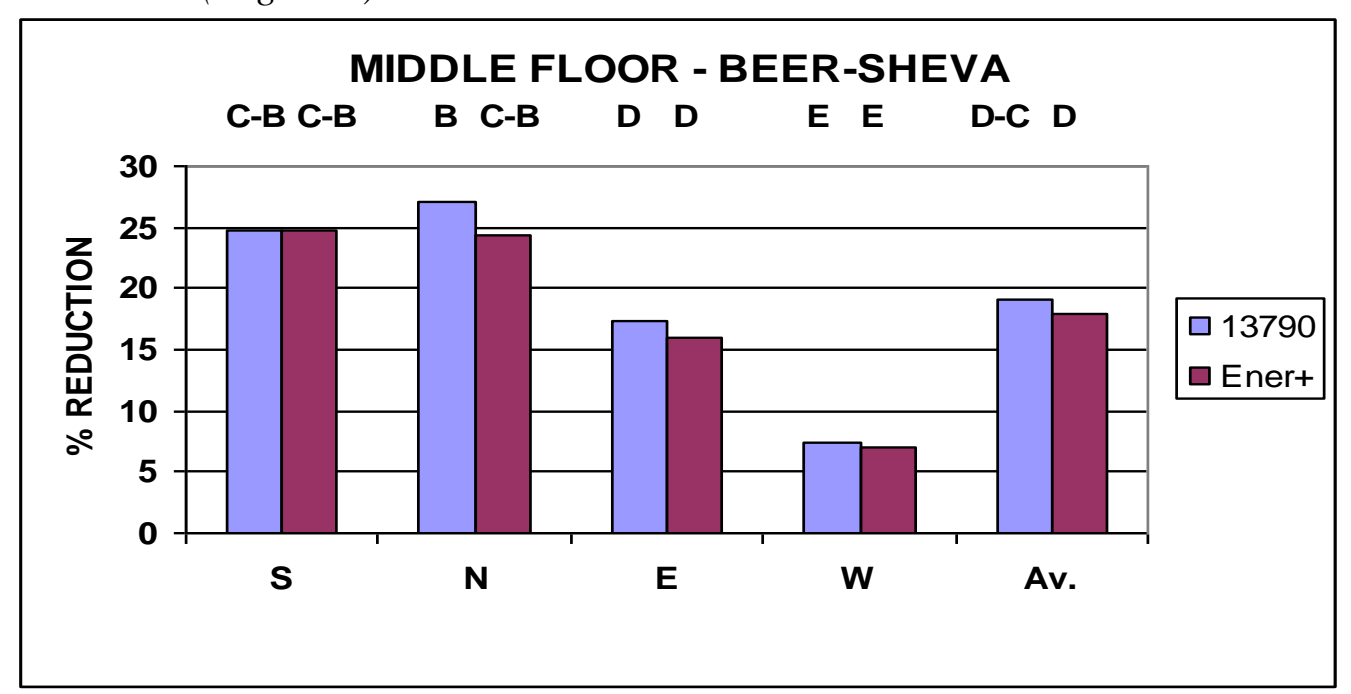


Figure 5C. Reduction of Heating + Cooling Energy for Middle Floor Apartment - Jerusalem (Region C)

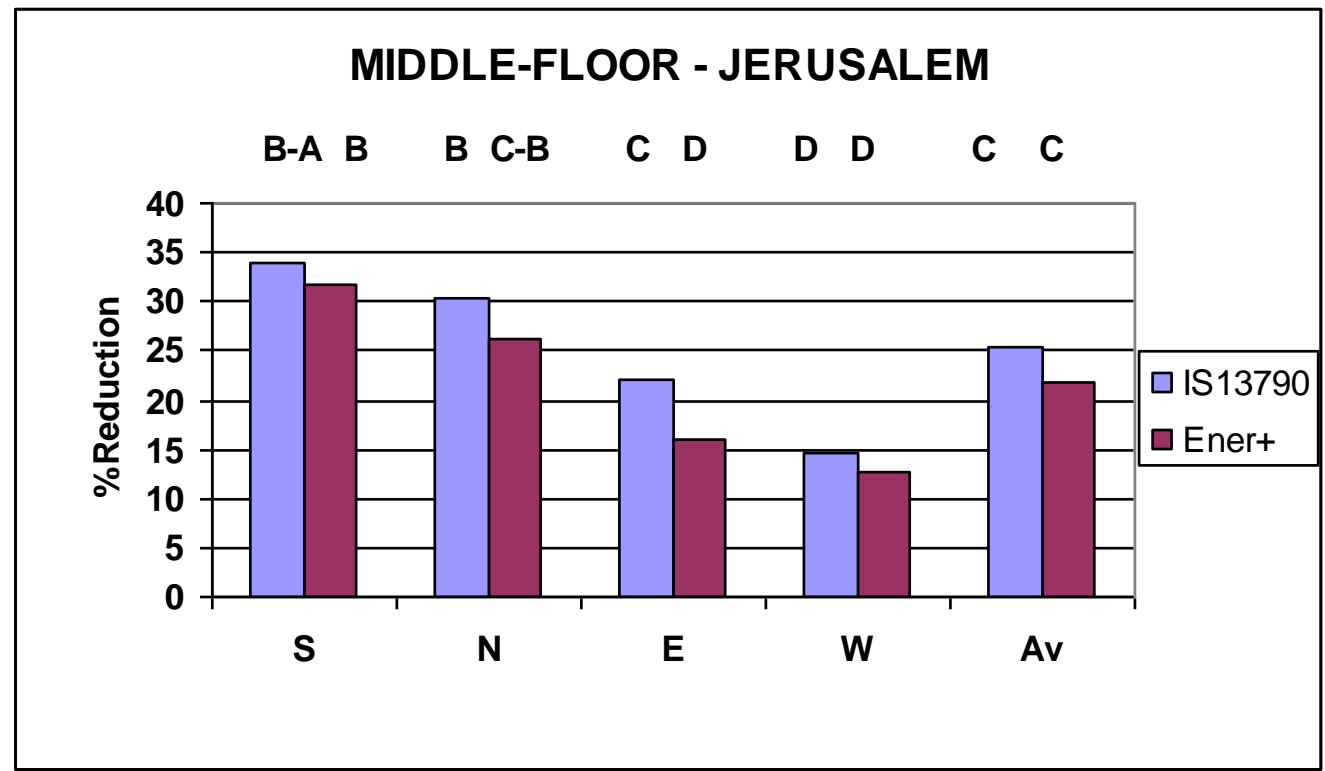

Figure 5D. Reduction of Heating + Cooling Energy for Middle Floor ApartmentEilat (Region D)

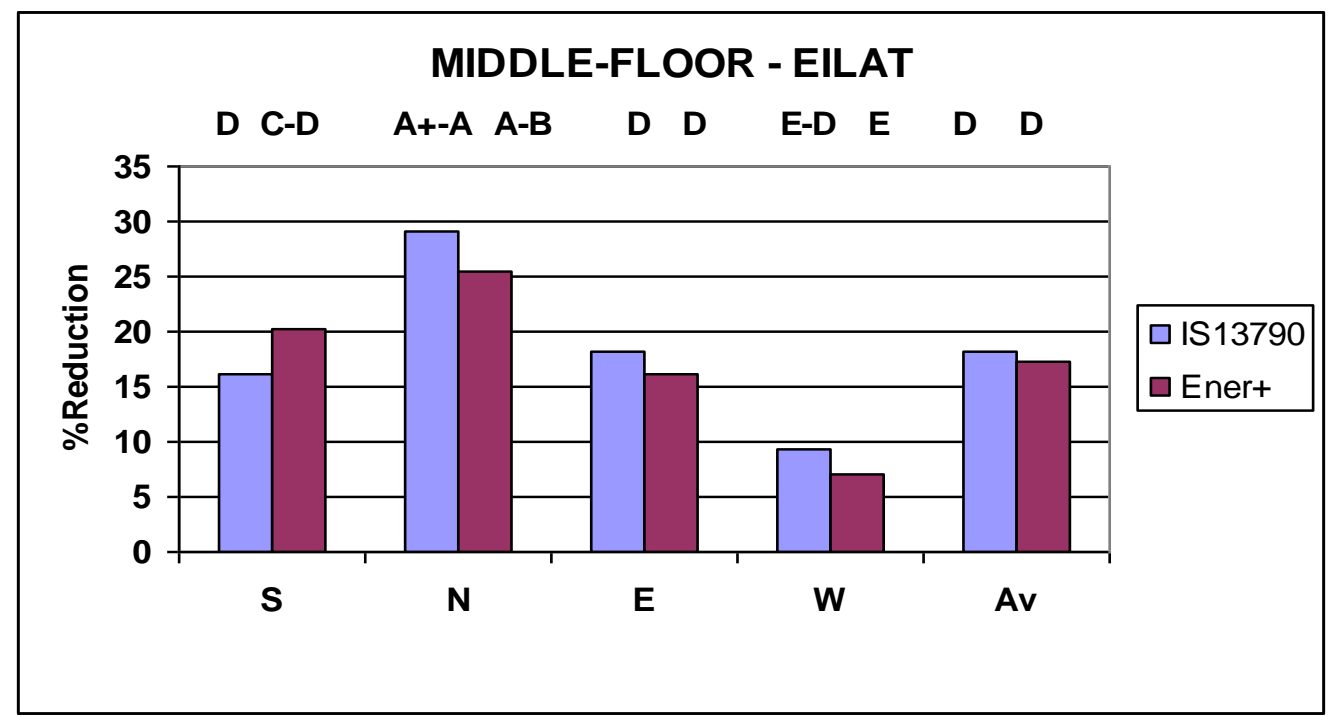

The reduction of the heating plus cooling energy as calculated by the two methods show an average difference of 3.4\%. This an average of $4.2 \%, 2.6 \%$, $5.1 \%$ and $3 \%$ for Climatic Zones A, B, C and D respectively or $2.7 \%, 1.5 \%, 6.5 \%$ and $4 \%$ for Middle Floor, Upper Floor, Upper Floor + Pilotis and Ground Floor respectively. This corresponds approximately to half a Category average (with borderline cases $\pm 1 \%$ from the limit between two categories) considered as halfway between the two neighboring categories). The calculations using ISO 13790 are generally slightly more "optimistic" than the ones of EnergyPlus (that by their nature are considered more reliable), i.e. the reduction of annual energy needs 
relative to the reference building is higher for the ISO 13790 monthly method calculations. This however does not necessarily mean that the actual total energy needs are smaller. The largest differences are encountered in the case of the Pilotis apartments - to some extent due to the difference in the algorithm used for calculating losses/gains through the elevated floor. In general, differences between the detailed EnergyPlus model and the very simplified monthly method of ISO 13790 are expected, since concentrating the temperature information for a month into one single monthly mean temperature is bound to lead to discrepancies and errors. This is particularly so when the month consists of different days with temperatures both above and below the set-point, as in Regions A and B especially during the transition seasons.

Figure 6A. Reduction of Heating + Cooling Energy for Upper Floor ApartmentBet-Dagan (Region A)

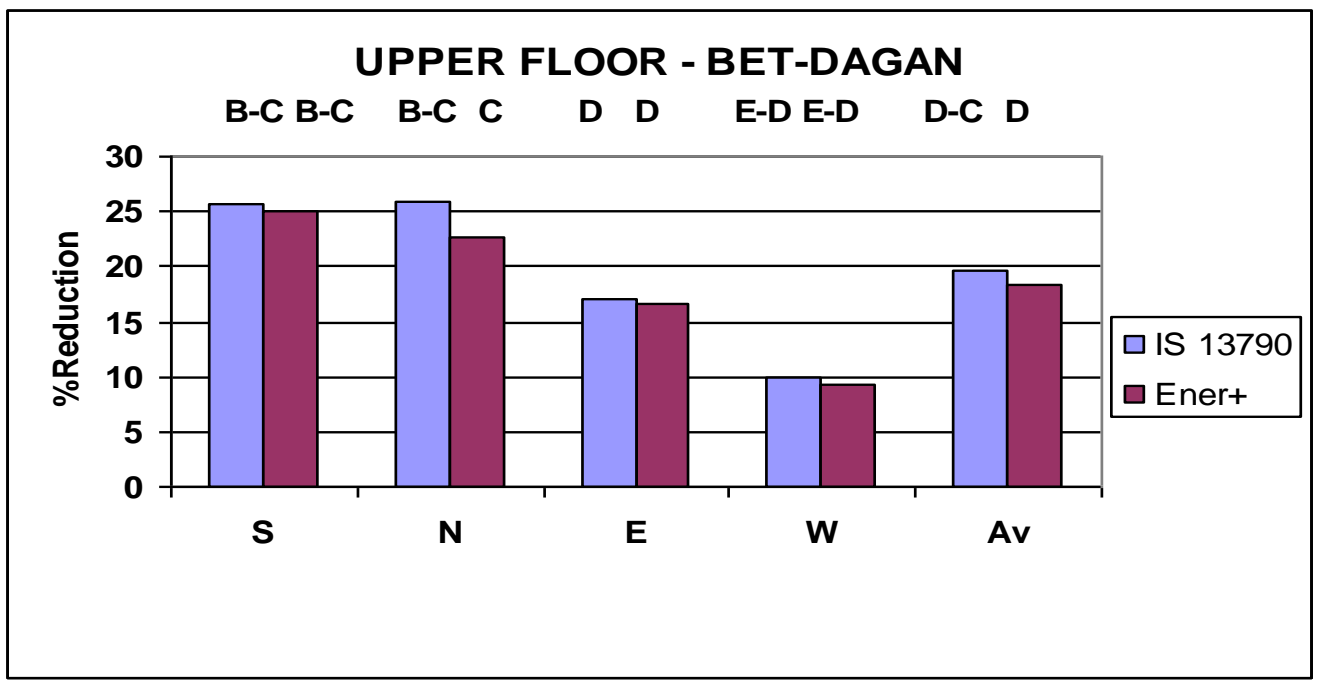

Figure 6B. Reduction of Heating + Cooling Energy for Upper Floor ApartmentBeer-Sheva (Region B)

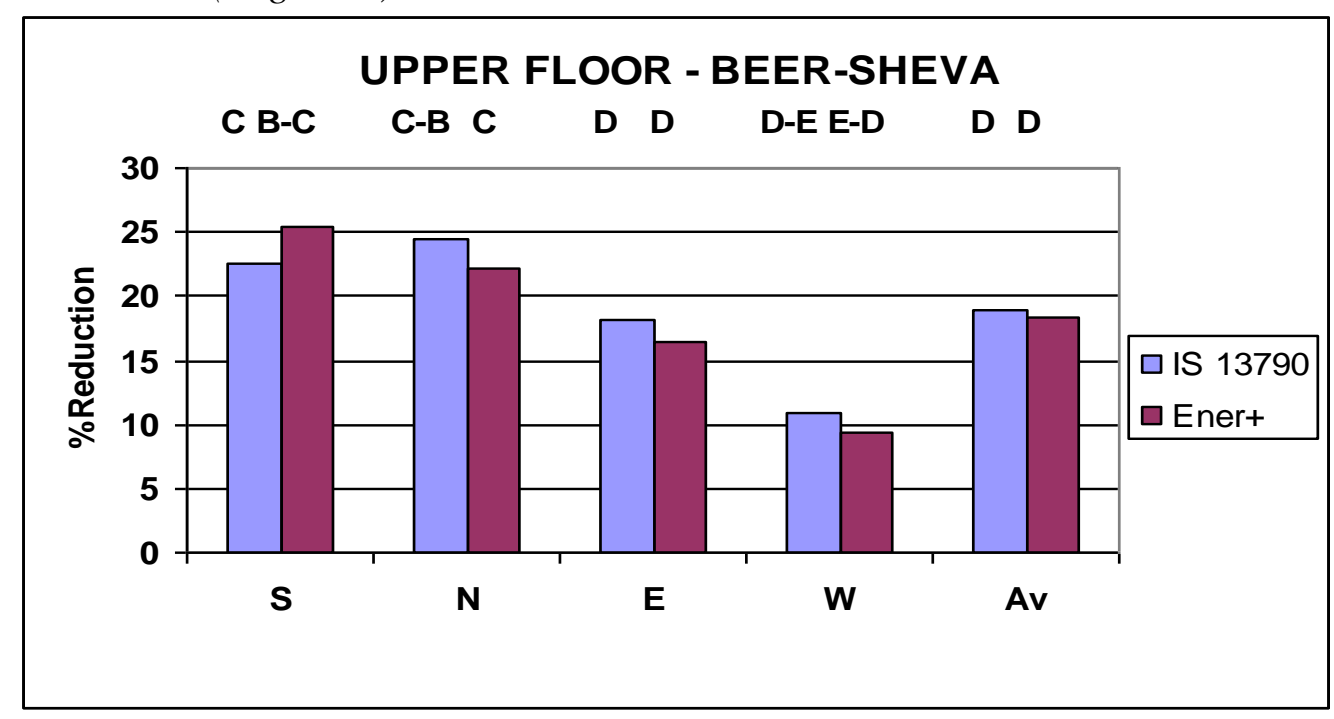


Figure 6C. Reduction of Heating + Cooling Energy for Upper Floor ApartmentJerusalem (Region C)

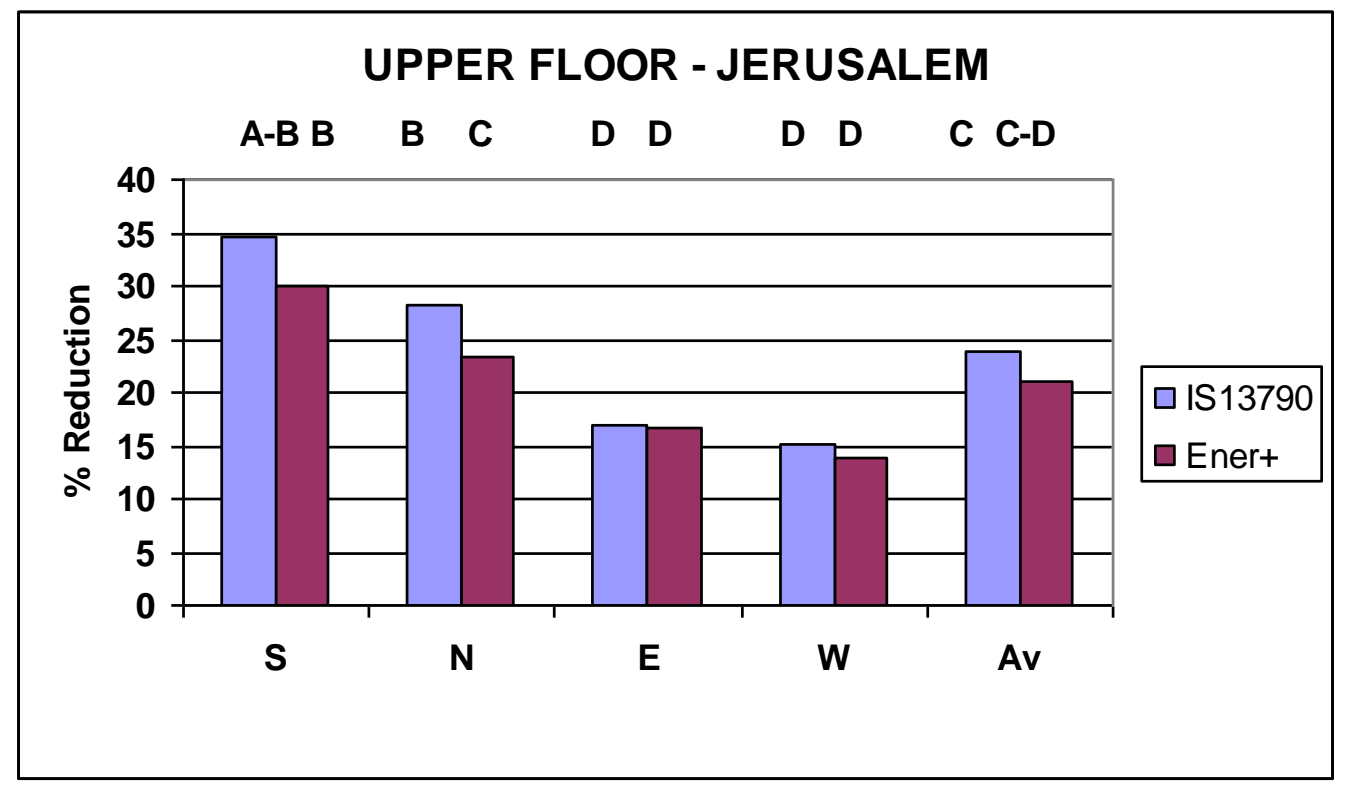

Figure 6D. Reduction of Heating + Cooling Energy for Upper Floor ApartmentEilat (Region D)

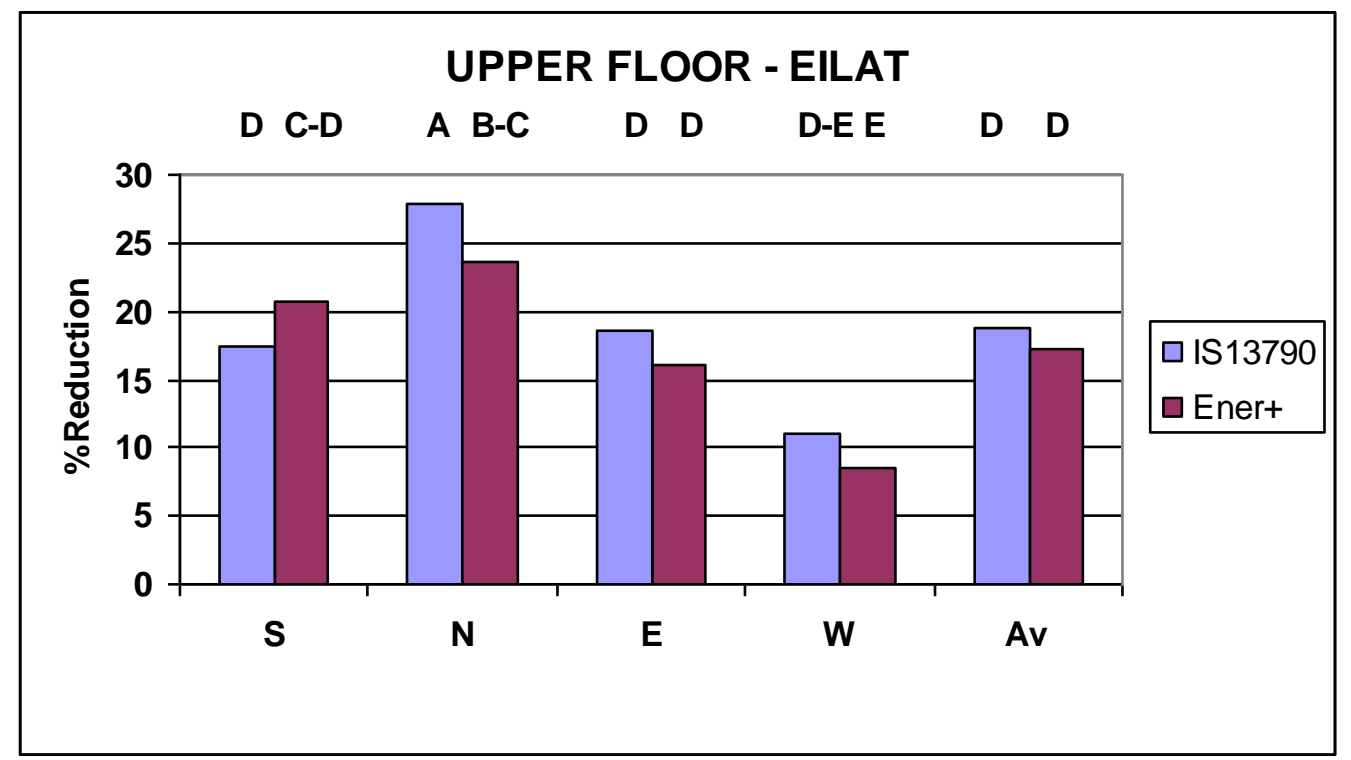


Figure 7A. Reduction of Heating + Cooling Energy for Roof + Pilotis Floor Apartment-Bet-Dagan (Region A)

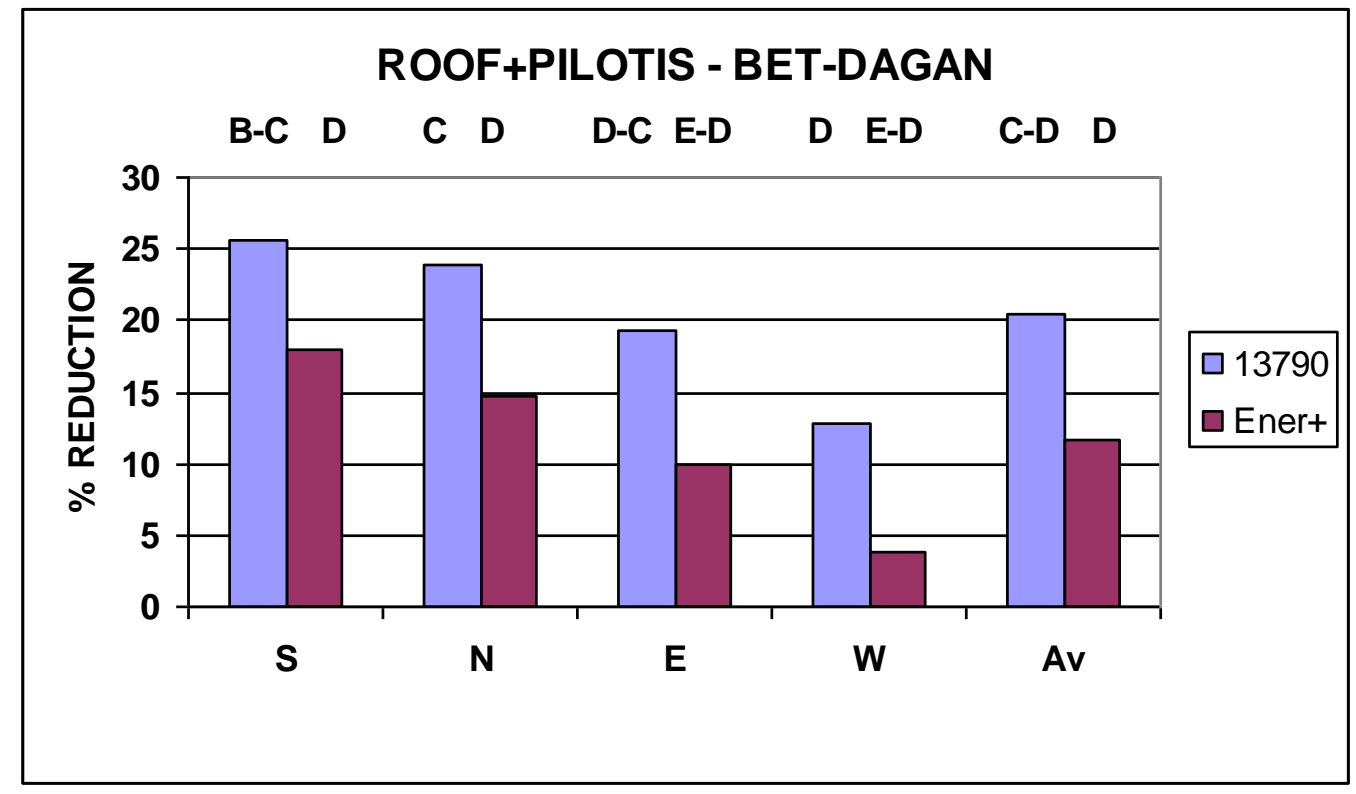

Figure 7B. Reduction of Heating + Cooling Energy for Roof+Pilotis Floor Apartment-Beer-Sheva (Region B)

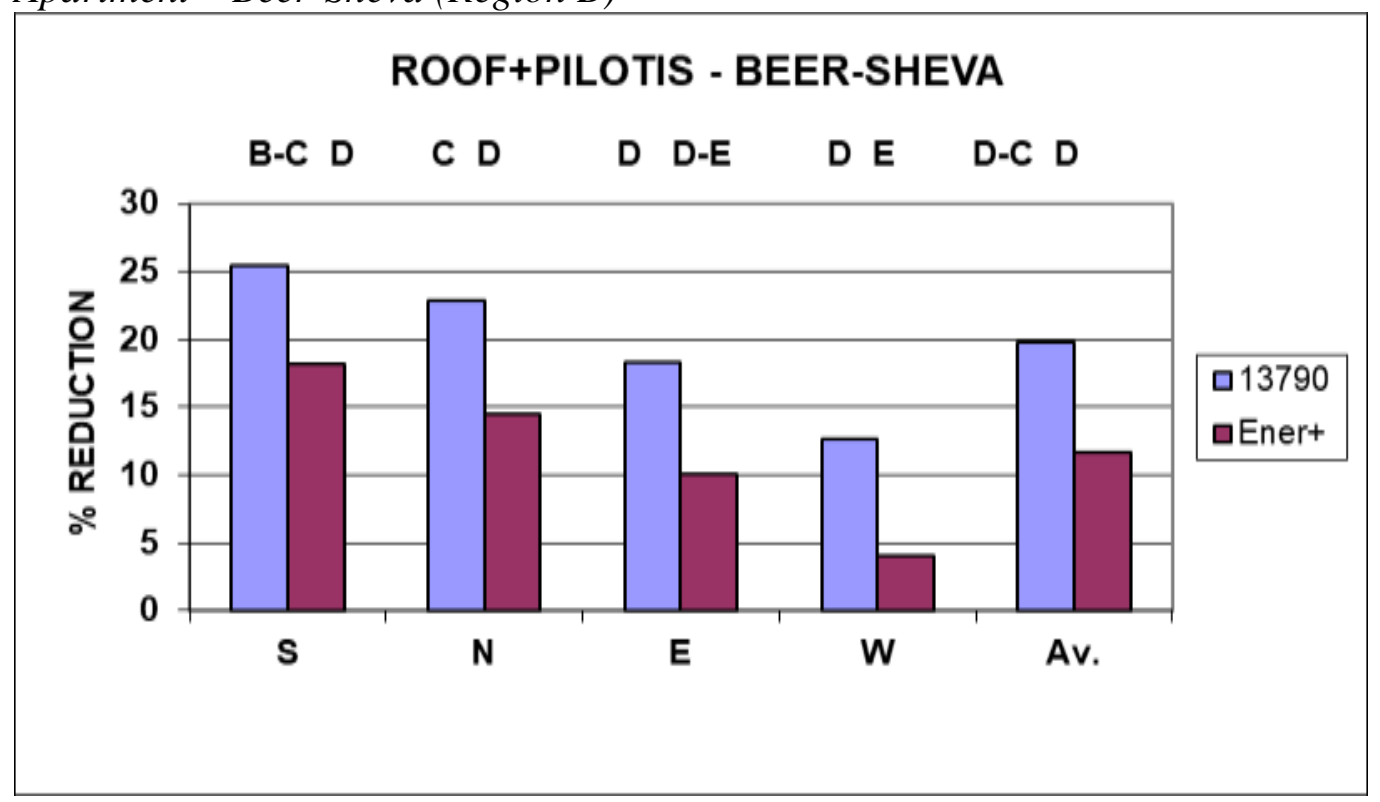


Figure 7C. Reduction of Heating + Cooling Energy for Roof + Pilotis Floor Apartment-Jerusalem (Region C)

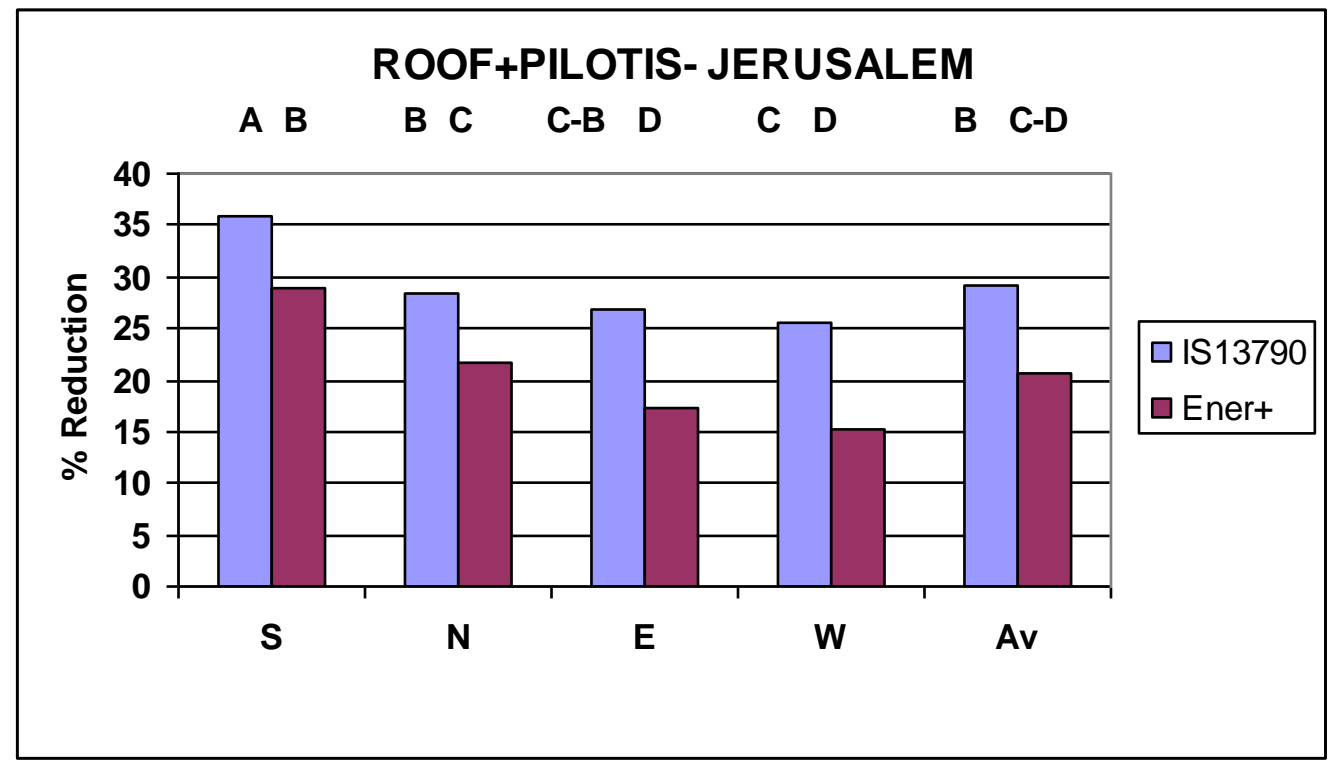

Figure 7D. Reduction of Heating + Cooling Energy for Roof + Pilotis Floor Apartment - Eilat (Region D)

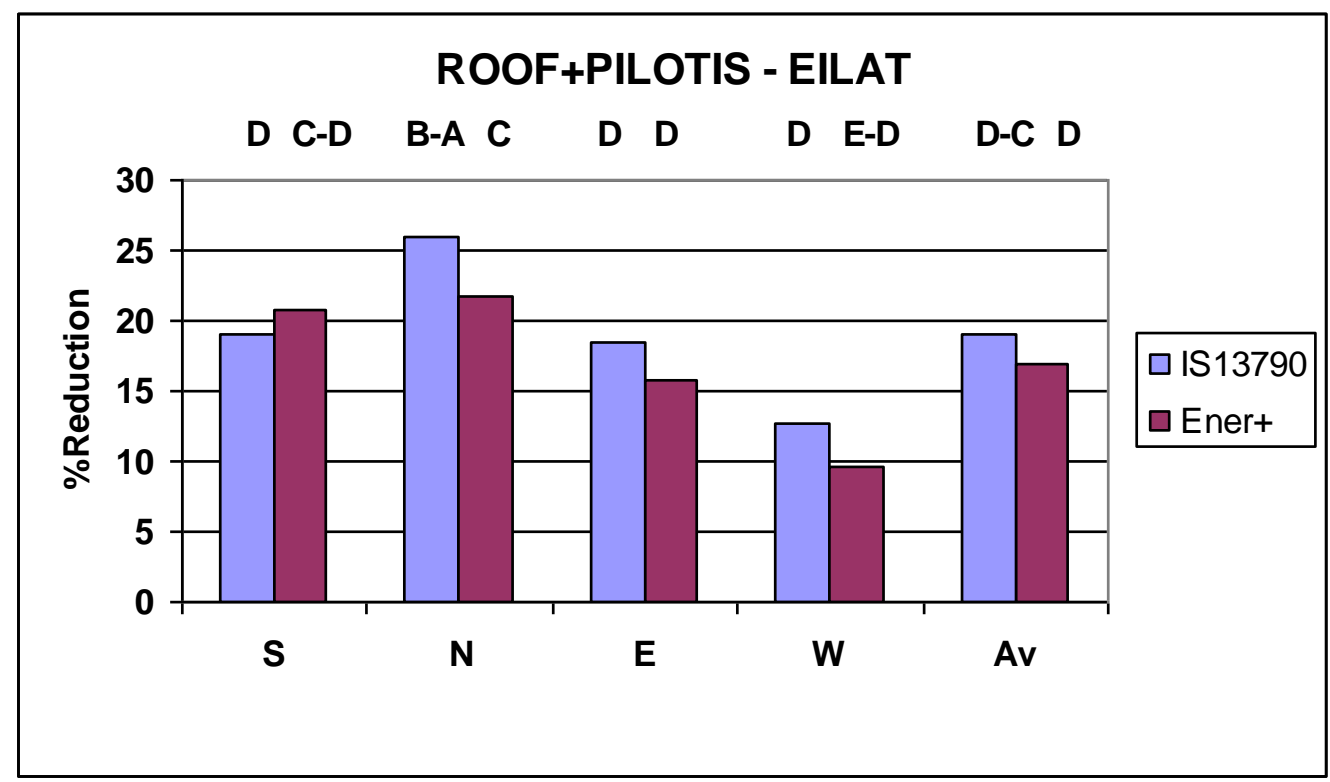


Figure 8A. Reduction of Heating + Cooling Energy for Roof + Ground Floor Apartment - Bet-Dagan (Region A)

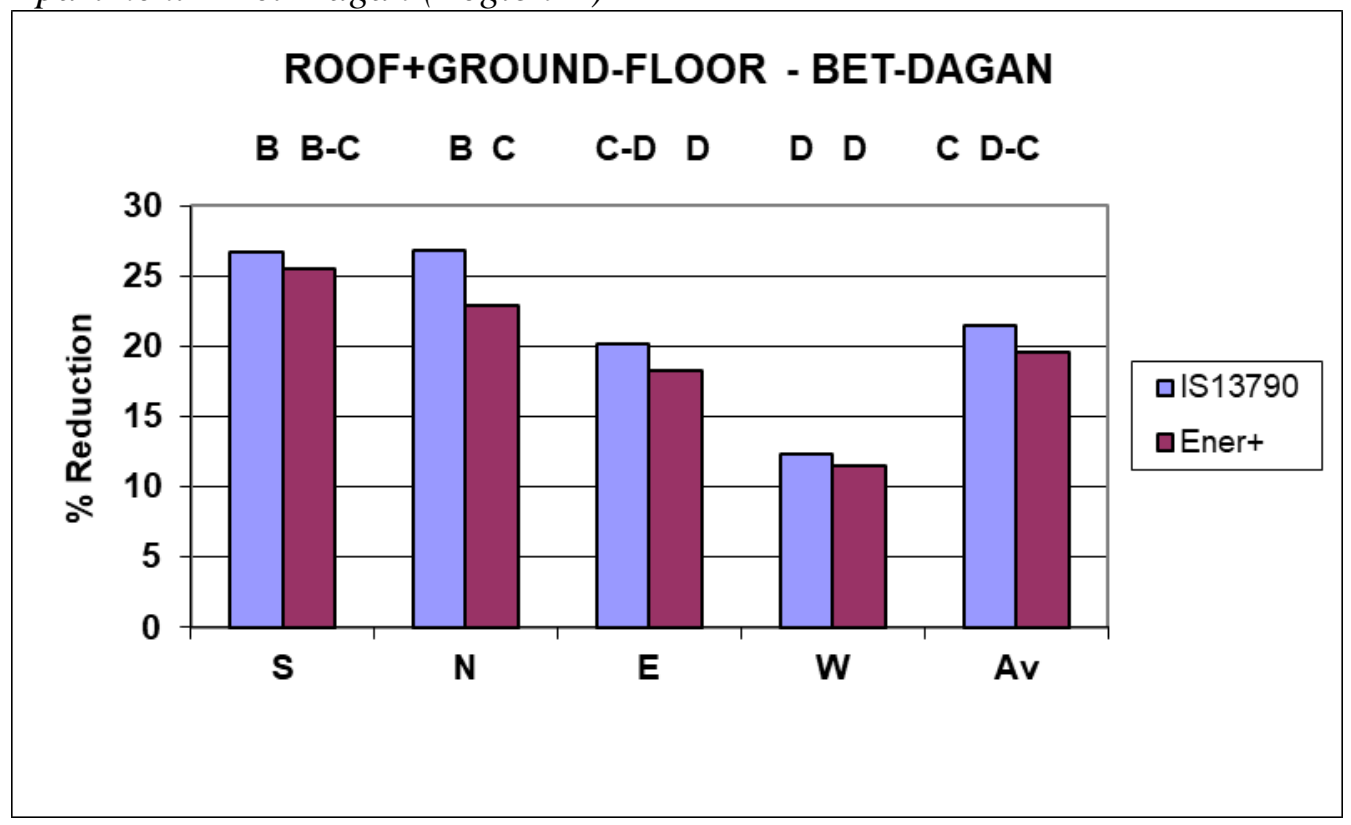

Figure 8C. Reduction of Heating + Cooling Energy for Roof + Ground Floor Apartment-Jerusalem (Region C)

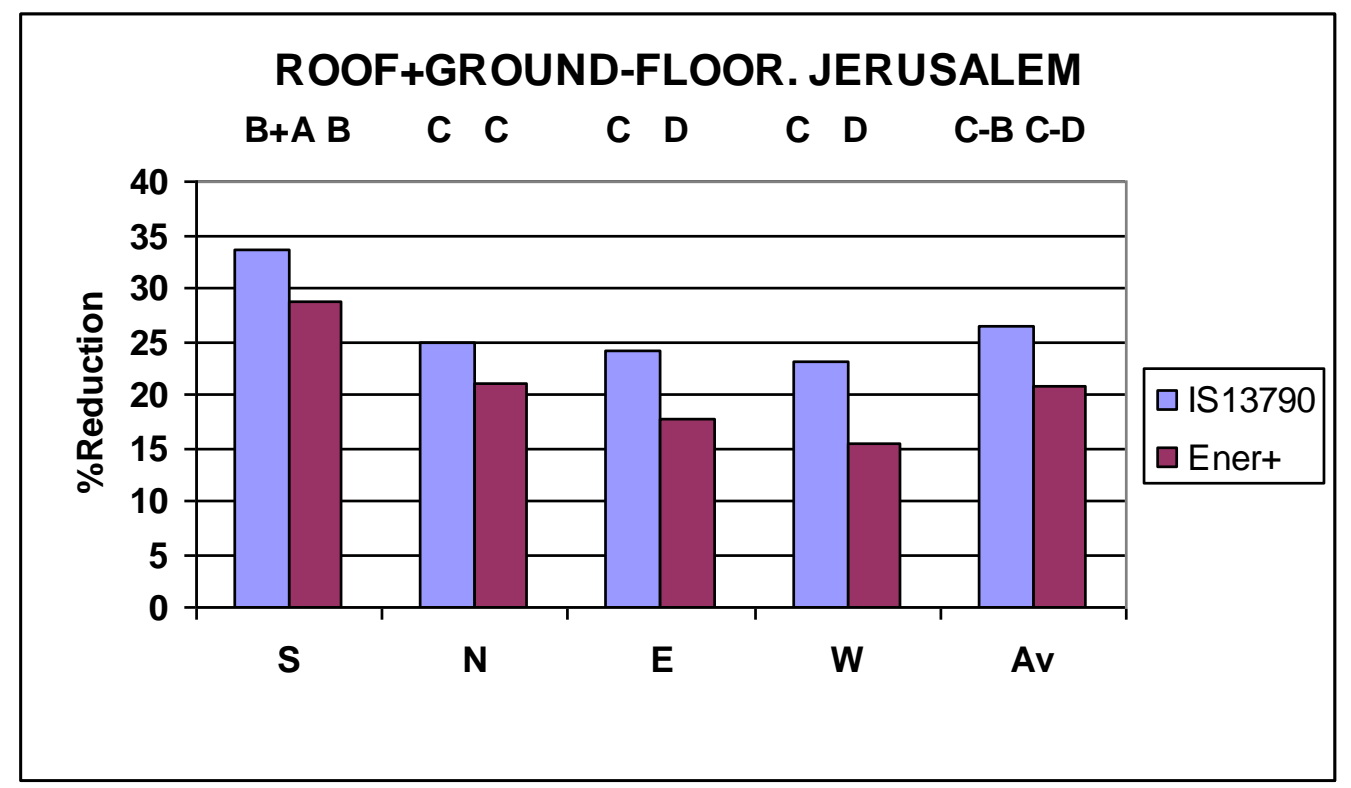


Figure 8D. Reduction of Heating + Cooling Energy for Roof + Ground Floor Apartment - Eilat (Region D)

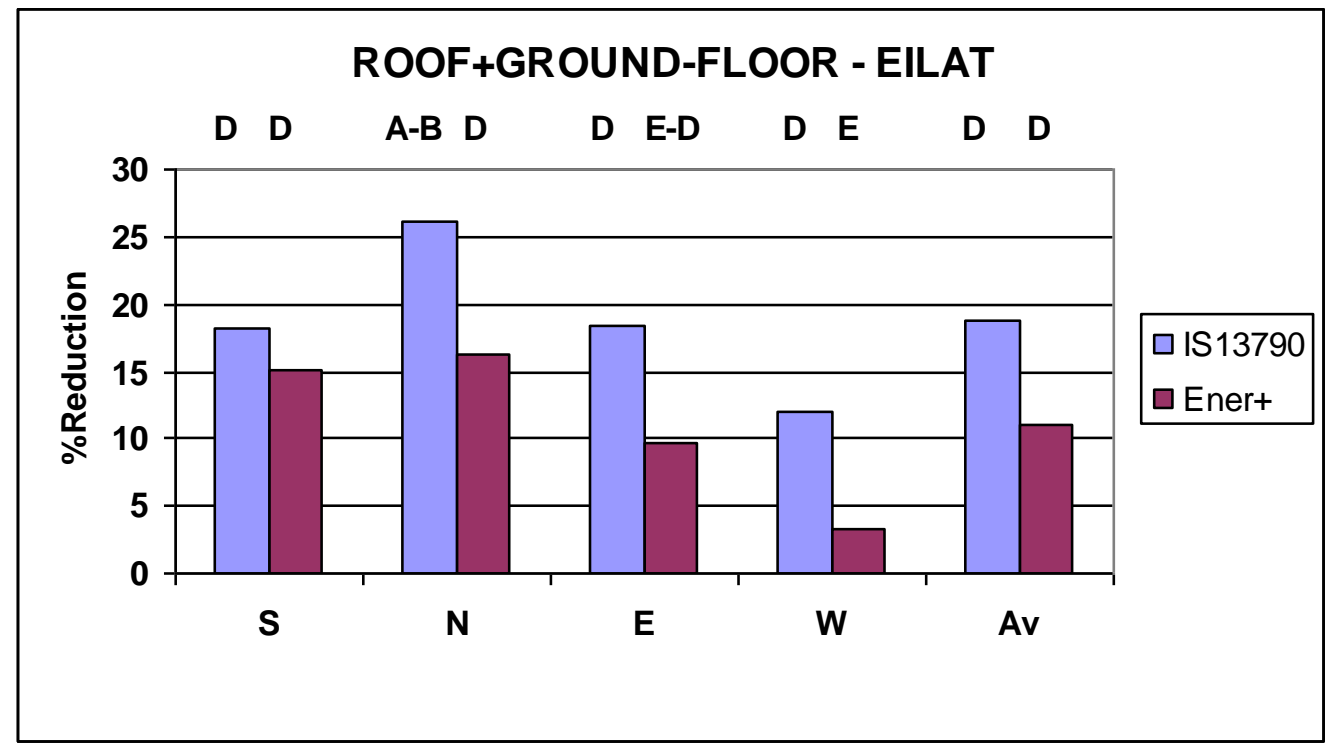

\section{Discussion}

The reduction of annual heating plus cooling energy per unit area as predicted by the ISO 13790, the most widely used simplified model, is compared to the one predicted by EnergyPlus, the most widely used comprehensive model, and shown to be in fair agreement for the four characteristic climatic zones in Israel. Of course, the comparison is not exhaustive and has many limitations.

The improved building is very similar in shape to the reference one - except for improved envelope properties and reduced infiltration. The choice of the reference apartment/building is itself problematic, given that apartments of different wall to area ratio and glazing to wall ratio have a different total energy per unit area.

For climatic zones A and B, where cooling dominates but heating is still substantial, this somehow hides bigger differences if one compares heating and cooling separately. The general agreement is slightly worse for heating-dominated Region C. Agreement is slightly better in exclusively-cooling region D, where for most of the year the effect of energy gains through the envelope and solar and internal gains is additive and the cooling energy efficiency factor $\square_{C}$ for the months accounting for most of the cooling energy is independent of the losses-tointernal-and-solar-gains ratio and equal to 1 . Based on predicted reduction of heating and cooling energy for the improved building, it is shown that the predictions of ISO 13790 are slightly optimistic (i.e. predict a bigger reduction relative to the chosen reference building).

There are many reasons that differences appear between the two methods, the monthly one of 13790 and EnergyPlus, which is far more reliable from the point of view of heat transfer processes, even though many simplifications are involved 
in it too. The theoretical basis of EnergyPlus is obviously much better, but ISO 13790 has the advantage that it is much more transparent whereas EnergyPlus to many frustrated constructers is considered an obscure black box. In Israel one can expect differences in the spring and the autumn, in which the weather is characterized by successions of cool and hot days and the mean monthly temperature as in ISO 13790 is insufficient to describe it. The contribution of these periods to annual energy needs however is relatively small.

As in all standards, the arbitrarily defined Categories may be problematic especially in the vicinity of borderlines between them. This is why it was chosen to show, for cases close to the borderline (less than 1\%), the alternative category, although this is not stipulated in the standards. Categories also become particularly problematic when the difference between the lower and the upper limit is only $3 \%$, less than the mean estimated difference between the two models examined here. In such circumstances it is possible for the two models to predict a difference of two categories - unacceptable when it comes to characterizing buildings.

The comparison is done for Israel climates only under idealized conditions, since the geometry of the compared buildings (the reference and the improved one) is the same. In an attempt to estimate the effect of wall-to-floor-area ratio, the effect of that ratio on total energy consumption (relative to the reference building) was calculated for different values of that ratio - both larger and smaller than the one relevant for the reference building, with the window area and the properties of the envelope are being kept constant. The difference between the predictions of EN 13790 and EnergyPlus is shown to vary between 0 and 10\%, depending on the climate, for the middle floor apartment. The effect of the wall-to-floor-area on the other kinds of buildings can be shown to be smaller, since there are conductive losses through the horizontal envelope elements, not affected by the differences of wall-to-floor-area ratio.

A sensitivity analysis of the results points that the relative energy reduction per unit area is more sensitive by 5 to $15 \%$ to changes in different parameters when calculated using ISO 13790 than with Energy Plus, for middle apartments. To estimate the effect of the wall-to-floor area, a sensitivity analysis of the reference building allowed for two alternative middle floor buildings - a $15 \times 10 \mathrm{~m}$ building and a $10 \times 7.5 \mathrm{~m}$ building - the first one for a wall-to-surface ratio of 1 $\mathrm{m} / \mathrm{m}^{2}$ and $1.4 \mathrm{~m} / \mathrm{m}^{2}$ respectively, compared to the $1.2 \mathrm{~m} / \mathrm{m}^{2}$ of the reference building. The window-to-floor area ratio is kept constant throughout and so is the internal loads per-unit area ratio. The predicted relative energy change in the case of the ISO 13790 was approximately $20 \%$ higher than the corresponding one of EnergyPlus for the three regions in which cooling is dominant but approximately $35 \%$ for Jerusalem. Similar results were found for changing the infiltration rate. The predicted ratio of the relative energy increase resulting from increasing the window was found to be $40 \%$ higher for ISO 13790 when compared to EnergyPlus. In general - the relative energy reduction/increase predicted by ISO 13790 is larger than the corresponding one by EnergyPlus.

The main problem though for cooling-dominated regions (not the coolingonly Eilat (D) region though, where the night outside air temperature is above the set point temperature required) - is that cooling by night ventilation is not taken 
into account as is the case of the requirements of Israeli Standard 5282. This may change the resulting classification radically in many cases. ISO 13790 proposes a monthly method that takes night ventilation into account, but is rather inappropriate for the Israeli conditions when there is a conductive and convective gain (as opposed to a loss) through the envelope. This is very important especially for zones A and B - since this way the importance of the cooling energy is increased and made dominant. Night cooling cannot be taken into account without differentiating between average night and day temperature. The monthly ISO 13790 calculation does provide for an approximate way to account for lack of cooling and increased air-flow rate during a part of the day, but it is still based on the average outside air temperature only and cannot properly take into account the difference between the day and the night temperature. This can only be accomplished by modifying the ISO 13790 monthly procedure so that the difference between the day and the night average temperature is somehow taken into account, as well as the storage of cooling energy in the building during the night. Note also that for the chosen all-day-cooling (and all-day-heating) pattern the internal thermal mass has a much smaller influence than it does in the case of partially heated and partially cooled buildings.

Another important problem for some cooling-dominated regions - not Region $\mathrm{D}$ where humidity is low - is accounting for latent heat. This may be particularly important in the Mediterranean Coastal Region A where it can account for up to $30 \%$ of actual cooling energy. This can be done with EnergyPlus, but ISO 13790 is not concerned with calculating latent heat. It can be modified appropriately by adding to the sensible heat either the latent heat involved in reducing the humidity ratio to the one of the dew point at the set-point temperature - or to a relative humidity at the set-point temperature of, say, 50\%. Of course, the actual reduction in the humidity ratio depends on the cooling system and equipment, which cannot be properly modelled by a monthly method. A standard for latent heat approximate estimation is currently elaborated (Standard EN ISO 52016-1) ${ }^{11}$.

The appropriateness of a $24 \mathrm{~h}$ cooled and heated building can also be questioned, since most buildings in Israel, especially in Regions A, B and C which account for the vast majority of the population, are not operated in this mode. The reasoning behind it is to estimate the maximum energy savings potential of the building, but when later in a post-occupancy evaluation study one compares the calculation procedure with actual results, one can expect substantial differences. The shading (and ventilation) strategies which are central for energy conservation during cooling periods cannot be properly taken into account using the monthly ISO 13790, even in the simplified way that they are required by IS 5280 .

\footnotetext{
${ }^{11}$ EN ISO 52016-1 Energy performance of buildings - Calculation of the energy needs for heating and cooling, internal temperatures and heating and cooling load in a building or building zone Part 1: Calculation procedures (in preparation).
} 


\section{Conclusions}

It is attempted to address the problem whether monthly ISO 13790 - the most well-established simplified energy model and the basis of energy classification of buildings in most countries of the EU - is appropriate for Israel, but also, indirectly, for many countries with similar climate where the cooling period is the dominating one. It can be concluded that the monthly ISO 13790 can serve as an alternative to EnergyPlus, the most common comprehensive building energy estimation model, in calculations for energy standards and energy ratings in simple cases (Residential Buildings for example) - but caution should be used and one can expect some deviations between the calculated and the actually achievable energy efficiency. It is shown that in the hottest (almost cooling only) region the difference between the two models is actually smaller than in other regions with both heating and cooling.

It is desirable to integrate in the monthly ISO 13790 method a way to account for night ventilation - an imperative for some climates where cooling is at least or more important than heating. The present method in ISO 13790 for taking into account night ventilation is not always appropriate for climates where cooling is the predominant consideration - since the difference between the night and the day temperature is not properly taken into account. In addition - the latent heat should also be considered, using the ISO standard currently under preparation, in hot and relatively humid climates - since it can easily account for $30 \%$ or more of the cooling energy - and cannot be reduced by the usual passive cooling strategies of shading and night ventilation.

\section{Acknowledgements}

The advice and help of Dr. Rokia Raslan, Architect Y. Schwartz and Prof. T. Oreszczyn of University College, London and of Prof. E. Erell of the Desert Research Institute, Ben-Gurion University of the Negev, Israel, are gratefully acknowledged.

\section{References}

Crawley, D. B., Hand, J. W., Kummert, M. and Griffith, B. T. 2005. "Contrasting the capabilities of building energy programs programs." US DOE, University of Strathclyde and University of Wisconsin.

Kalema, T., Johanesson, G., Hagengran, P. and Elmarsson, B. 2008. Accuracy of energy analysis of buildings: A comparison of a monthly energy balance method and simulation methods in calculating the energy consumption and the effect of thermal mass. Journal of Building Physics 32, p. 101-130.

Kokogiannakis, G., Strachan, P. and Clarke, J. 2008. Comparison of the simplified methods of the ISO 13790 standard and detailed modelling programs in a regulatory context. Journal of Building Performance Simulation 1, p. 209-219. 
Raslan, R. and Davies, M. 2010. Results variability in accredited building energy performance compliance demonstration software in the UK: an inter-model comparative study. Journal of Building Performance Simulation 3, p. 63-85.

Raslan, R. and Davies, M. 2012. Legislating building energy performance: putting EU policy into practice. Building Research \& Information 40, p. 305-316.

Schwartz, Y. and Raslan, R. 2013. Variations in results of building energy simulation tools, and their impact on BREEAM and LEED ratings: A case study. Energy and Buildings 52, p. 350-359.

Summerfield, A., Raslan, R., Lowe, R. and Oreszczyn, T. 2011. How useful are building energy models for policy? A UK perspective. IBPSA 12, p. 2477-2482.

Zhou, X., Hong, T., Yan, D. 2013. Comparison of Building Energy Modeling Programs: HVAC Systems. Ernest Orlando Lawrence Berkeley National Laboratory LBNL6432E (2013). 